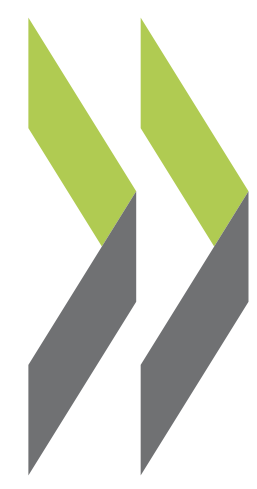

OECD Local Economic and Employment Development (LEED) Papers 2013/05

\title{
Lódzkie Region: \\ Demographic Challenges Within an Ideal Location
}

\section{Piotr Szukalski,}

Cristina MartinezFernandez,

\section{Tamara Weyman}


ŁÓDZKIE REGION: DEMOGRAPHIC CHALLENGES WITHIN AN IDEAL LOCATION 
This work is published on the responsibility of the Secretary-General of the OECD. The opinions expressed and arguments employed herein do not necessarily reflect the official views of the Organisation or of the governments of its member countries.

This document and any map included herein are without prejudice to the status of or sovereignty over any territory, to the delimitation of international frontiers and boundaries and to the name of any territory, city or area. 


\section{ORGANISATION FOR ECONOMIC CO-OPERATION AND DEVELOPMENT}

The Organisation for Economic Co-operation and Development (OECD) is a unique forum where the governments of 34 market democracies work together to address the economic, social and governance challenges of globalisation as well as to exploit its opportunities. The OECD's way of working consists of a highly effective process that begins with data collection and analysis and moves on to collective discussion of policy, then decision making and implementation. Mutual examination by governments, multi-lateral surveillance and peer pressure to conform or reform are at the heart of the OECD's effectiveness. Much of the material collected and analysed at the OECD is published on paper or online: from press releases and regular compilations of data and projections to one-off publications or monographs on particular issues; from economic surveys of each member country to regular reviews of education systems, science and technology policies or environmental performance. For more information on the OECD, please visit www.oecd.org/about.

\section{LOCAL ECONOMIC AND EMPLOYMENT DEVELOPMENT (LEED)}

The OECD Programme on Local Economic and Employment Development (LEED) has advised governments and communities since 1982 on how to respond to economic change and tackle complex problems in a fast-changing world. Its mission is to contribute to the creation of more and better quality jobs through more effective policy implementation, innovative practices, stronger capacities and integrated strategies at the local level. LEED draws on a comparative analysis of experience from the five continents in fostering economic growth, employment and inclusion.

ISSN 2079-4797 (PDF) OECD Local Economic and Employment Development (LEED) Working Paper Series. This report is part of a series of working papers from the OECD Local Economic and Employment Development (LEED) Programme. The LEED Programme identifies, analyses and disseminates innovative ideas for local development, governance and the social economy. Governments from OECD member and non-member economies look to LEED and work through it to generate innovative guidance on policies to support employment creation and economic development through locally based initiatives. 


\section{ACKNOWLEDGEMENTS}

This report was prepared by Piotr Szukalski, Institute of Sociology, University of Lodz, Poland, with Cristina Martinez-Fernandez and Tamara Weyman. The paper was prepared under the supervision of Dr Cristina Martinez (OECD LEED Programme). Dr Tamara Weyman (consultant) provided research and editorial assistance. The paper has been reviewed by Naoko Kubo (consultant) and Antonella Noya (OECD LEED Programme). Melissa Telford edited the report, and Elisa Campestrin and Francois Iglesias provided technical support.

The paper has benefited from the valuable comments of Przemysław Herman and Michał Sułkowski from the Ministry of Regional Development under the supervision of Mr Pawel Chorazy, Director, Department for European Social Fund Management. Thanks also for the significant inputs that were provided by the international experts who participated in the OECD study mission to Łódz in March 2012: Dr. Jasper Van Loo (CEDEFOP); Mr. Aldert de Vries and Ms. Roxana Chandali (Ministry of Interior and Kingdom Relations of the Netherlands); and Naoko Kubo and Antonella Noya (OECD).

The authors would also like to extend thanks to the representatives and officers of the Lódzkie Marshall's Office, and to all provincial and local authorities and institutions who participated in meetings, workshops and study visits and provided documentation and comments vital to the production of the report.

This Working Paper is part of a series of studies of the Organisation for Economic Co-operation and Development's (OECD) Local Economic and Employment Development (LEED) Programme on "Local Scenarios of Demographic Change". This study is conducted with the support of the Ministry of Regional Development, Poland and the Łódzkie Regional Government. 
TABLE OF CONTENTS

ORGANISATION FOR ECONOMIC CO-OPERATION AND DEVELOPMENT ….................................

LOCAL ECONOMIC AND EMPLOYMENT DEVELOPMENT (LEED) ................................................

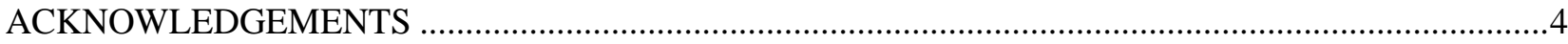

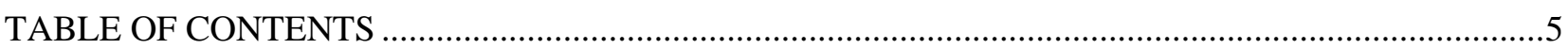

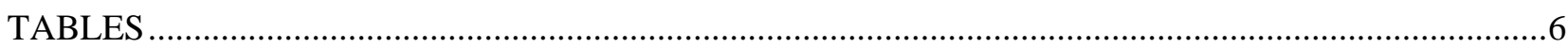

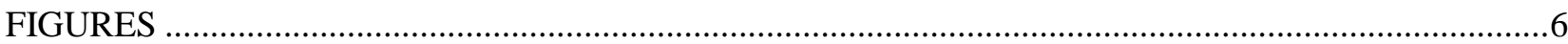

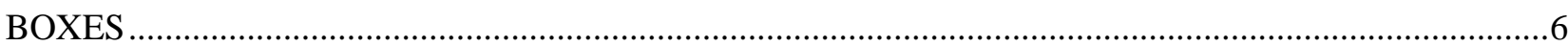

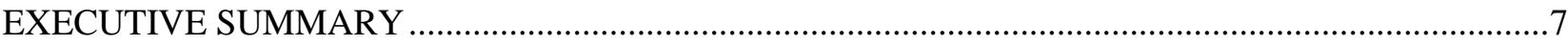

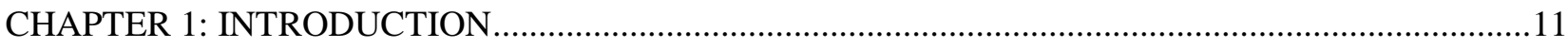

CHAPTER 2: CHARACTERISTICS OF THE ŁÓDZKIE REGION ……................................................13

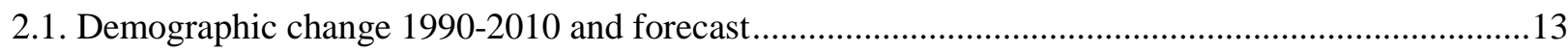

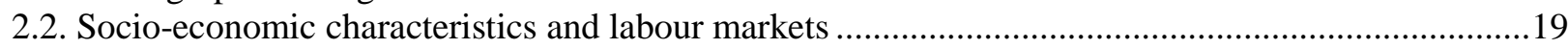

CHAPTER 3: OLDER WORKERS: SILVER ECONOMY AND WHITE ECONOMY ..........................26

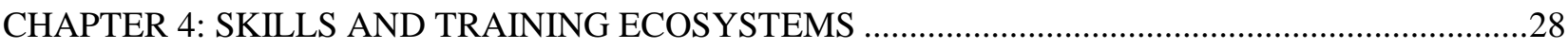

CHAPTER 5: HEALTH SERVICES FOR SOCIAL TRANSFORMATION AND INCLUSION ...............31

CHAPTER 6: GREEN REGIONAL/INDUSTRIAL ATTRACTIVENESS …..........................................34

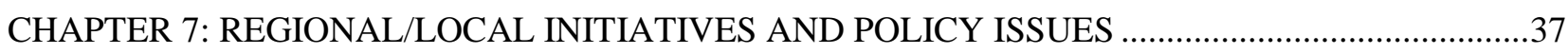

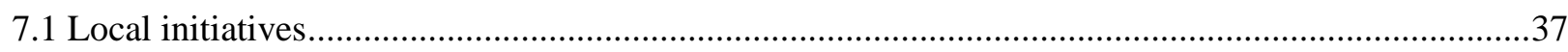

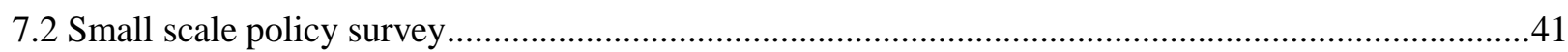

CHAPTER 8: KEY FINDINGS AND RECOMMENDATIONS FOR ŁÓDZKIE......................................45

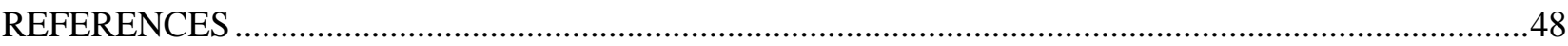

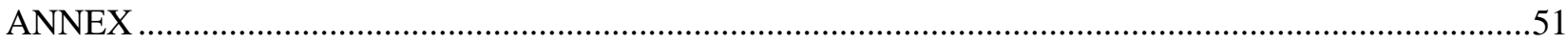




\section{TABLES}

Table 1 Structure of employment by sectors of economy, 2010 20

Table 2 Self-assessment of the health condition (as a percentage of adults who have declared their specific health condition) in Poland and Łódzkie Region between 1996 and 2009 32

\section{FIGURES}

Figure 1 Lódzkie region - administrative division

Figure 2 Population living in Łódzkie region, 1995-2010 and projections 2011-2020 ........................... 13

Figure 3 Population living in Łódź, 1970-2030 ............................................................................... 14

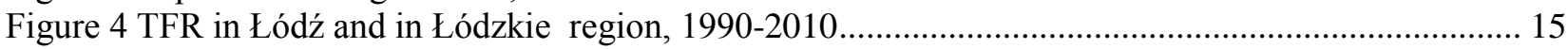

Figure 5 Life expectancy by sex in Łódź and in Łódzkie region, 1990-2010 .......................................... 16

Figure 6 Age-specific mortality rate among male and female inhabitants of Łódź and Łódzkie region in

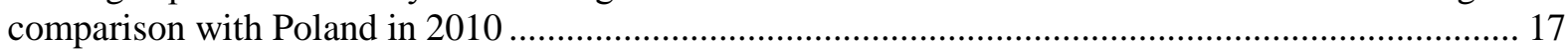

Figure 7 Age distribution of Łódzkie region population, 1990-2020 .................................................. 19

Figure 8 Changes in structure of employment by sectors of economy, 2002-2010_................................. 20

Figure 9 Employment rate for people aged 50+, 1995-2011 ................................................................ 26

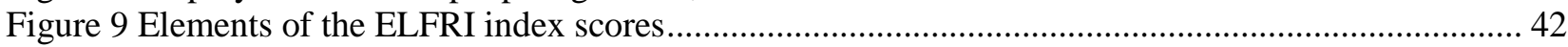

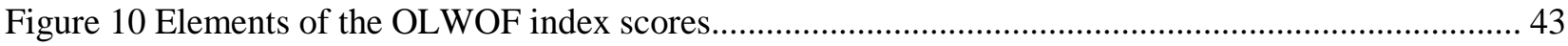

\section{BOXES}

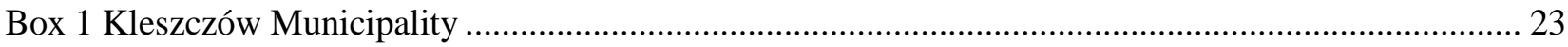

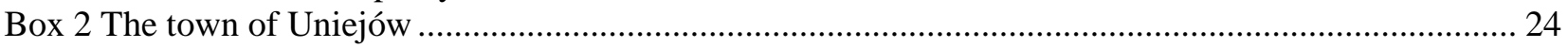

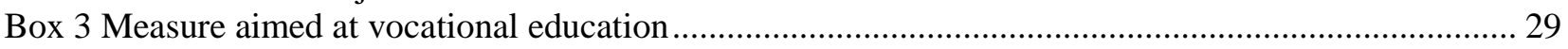

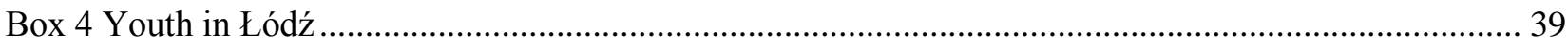

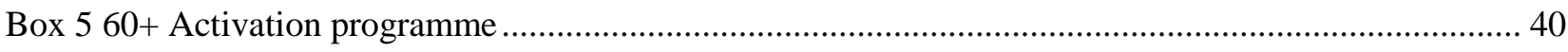

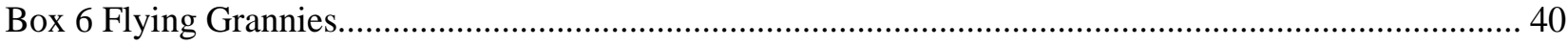




\section{EXECUTIVE SUMMARY}

Demographic change is one of the key challenges for local development in today's society; strategic solutions must take into account the interplay of elements within a particular local area of development. At the same time, there are opportunities to be fostered, such as the development of the silver economy of older entrepreneurs, the white economy of medical services for the elderly population, and the green economy.

This paper outlines the findings of the Poland case study for the Łódzkie region for the international project, Local scenarios of demographic change. The project is conducted by the Organisation of Economic Development and Co-operation (OECD) Local Economic and Employment Development (LEED) Programme, with the support of the European Commission DG Employment, Social Affairs and Inclusion. The analysis in Poland was conducted in partnership with the Ministry of Regional Development and the regions of Pomorskie, Łódzkie and Małopolska.

The Łódzkie region is located in the central part of Poland, at the intersection of several major arterial roads; Berlin-Moscow and Gdańsk-Vienna. Despite the excellent location, the region is affected by several demographic challenges, partly related to the region's proximity to Warsaw, the Polish capital city. The official strategic documents of regional development have been focused on "hard" infrastructure development, with limited attention being paid to current or future demographic and social challenges, such as the declining and ageing population, which pose significant obstacles to future regional development. Profound public interest in demographic change, however, has resulted in the creation of a plan for 2013-2014 to forestall this predicted depopulation, and also in the preparation of a demographic development strategy for the years following that.

The findings of the regional study highlight the following issues:

- The Łódzkie region is experiencing population decline primarily due to two causes: negative natural increase (with fertility levels well below replacement levels); and a negative migration balance (with many residents moving to Warsaw for education and employment opportunities). This decline in population, according to the Polish Central Statistical Office, will continue right through into the year 2035, resulting in a loss of youth and skilled professionals for the region, unless strategic decisions are made to rectify the situation.

- Also of significance is that the Łódzkie region, especially the city of Łódz, has the highest mortality rate in the country, due to very high rates of cardiovascular disease among persons aged 20 to 50, with a resulting low life expectancy, particularly for males. Other medical issues include liver and digestive system disease, pneumonia, respiratory system diseases and traffic accidents, which are all related to the quality of life and social environment. The region is also experiencing accelerated ageing of the population; in 2010, $15 \%$ of the population was over 65, but according to the Polish Central Statistical Office, this is projected to reach 25\% by 2035.

- The Lódzkie labour market characteristics are influenced by its economic structure, with declining importance on agriculture, but increasing employment in industry and services areas. 
Unemployment in the region was $12.2 \%$ in 2010 , however, this rate depends on the individual poviats (counties), with some districts experiencing an unemployment rate as high as $17.7 \%$.It should be noted also that a large proportion of the economic entities in the region are smallmedium enterprises (SMEs), and more than $90 \%$ of these firms are privately owned, with one-third of them operating within the trade sector.

- The region has been experiencing slight ageing of the workforce; from 1995-2011, employment of people aged $50+$ increased from $28 \%$ to $31.2 \%$. The region has been attempting to increase the professional activity of people aged $45+$ by information dissemination, and by looking at the criteria against which employers evaluate employees and job candidates. Unfortunately, there was not a lot of data available relating to the silver economy, however, the increasing number of pensioners whose income is relatively stable means they should be treated as potential resources, with increasing importance, as they are the elderly consumers of the future. The Łódzkie region has a well-developed healthcare network, with programmes particularly set up to target children's health. However, there are currently no programmes directed at the elderly, or focused on health promotion for those in their 20s-40s, despite the high mortality rates in the region.

- The region has significant educational potential due to its proximity to Warsaw. Offsetting this positive feature, however, is the fact that it is faced with a weak labour market, thereby reducing job opportunities for graduates, and a lack of co-operation between universities and employers. Significantly, the region is dominated by the three largest state institutions for higher education, and has been extending its didactic offerings, as part of government programmes supporting innovative specialisations. Importantly, the region lacks comprehensive adult education solutions. The weakness of institutional forms of adult education has been partly compensated by the Universities of the Third Age (UTAs), which are educational entities aimed at retired people. The UTAs can be seen as being a useful tool for activating and motivating retirees, offering information technology (IT) training and language courses, both of which help combat elderly social exclusion.

- The analysis of health services for social transformation and inclusion shows that the overall number of people requiring social assistance within the Łódzkie region has declined, however, there is a worrying concentration of the poorest people into poverty pockets increasingly occurring in the cities within the region. Furthermore, the region is beginning to be characterised by the phenomenon of inherited social assistance beneficiary status (ie second and third generations living on social assistance alone). Reasons for seeking social assistance support include poverty, unemployment, long-term illness, and disability. The poor are predominately families with children.

- The Łódzkie region also has a higher percentage of alcohol consumption when compared with the national average, especially among young people. The poor condition of the regional population may result from stress, with $6.3 \%$ of the population aged 16 to 65 stating that they are stressed, with a further $31.8 \%$ declaring that they experience a high frequency of stress.

- Regarding the green regional/industrial attractiveness of the region, although Łódzkie has not previously been considered attractive to tourists, and therefore has poorly developed tourist facilities, recently, the geothermal springs have proved attractive to visitors, both for therapy and for leisure. The region's advantages also include: location (proximity to Warsaw); access to major workforce resources; vast scientific and research potential; natural resources of brown coal deposits (cheap electrical energy); thermal waters, forming the basis for both renewable energy development and tourism; and special economic sub-zones. The green economy could also be a potential growth area in the future. 
In the past, regional strategies have neglected the importance of demographic transition, but recently, a plan to combat depopulation has been developed, with emphases being placed on family, children, and work. The Strategy of Social Policy (2007-2020) focuses on: poverty; long-term unemployment; the crisis of family; social exclusion; addictions; equal opportunities for disabled people; the ageing society; and infrastructure and system support. Particular emphasis is often placed on 'hard' actions - the development of infrastructure, and attracting investments offering new jobs. However, strategies tend to neglect other 'soft' actions and social expenditure. What is primarily lacking, is a more comprehensive policy concerning social assistance directives, with social policy and assistance being orientated toward provision of material help for people with no income or those in a difficult situation, and strong promotion of active living at all stages of life.

The results of two regional questionnaires indicated a relatively poor result for Łódzkie as an Elderly Friendly Place to Live (ELFRI) and Older Workers Friendly Place to Work (OLWOF). The ELFRI had below average results (ratings are between 1 and 5, with 3 being considered average) for all areas: outdoor spaces and buildings; transport; housing (public and private); social participation; respect and social inclusion; civic participation and employment; communication and information; and community support and health services. The OLWOF also had a below average result for all areas: recruitment; work culture and opportunities; training and skills development opportunities; and company health and benefits. However, participants did the emphasise the importance of having friendly places to work for older workers, thus highlighting that there is a policy gap.

The results indicate that local and regional authorities are only undertaking reactive actions to depopulation and rapid ageing. As a consequence, there is no overall policy addressing demographic transformations, ageing of the population, and inadequate family policy. Key areas for future activities on which regional authorities could focus include: enhancing living standards to increase residential attractiveness; development of family policies intended to assist creation of stable family life, and introduction of economic instruments to support families; increasing the willingness of, and possibilities for, senior citizens to play an active role in society; improving human capital by providing access to education and health care that are adapted to the differing stages of life; and strengthening the city of Łódz's role as a metropolis (regional centre) for innovative technologies and economic growth.

Depopulation and population ageing will affect regional policy development at all levels, shaping labour markets, consumption, education, and family life. Primary elements for policy development are:

- Data, information and knowledge - demographic transitions at the local level should be diagnosed, to ensure social service requirements are met, and to prepare for the inevitable changes that will occur in the future. Promotion of demographic forecasts for regions and local areas by Statistics Poland could be done by the creation of a special institution focused specifically on making diagnoses, developing projections, and disseminating the results.

- Family-focused policies - provide conditions favourable for creating families, by helping to ensure stable professional careers, and facilitating vocational activities, such as childcare. Alternative methods of childcare should also be promoted via certified, registered and supervised mini-creche or in-home child carers.

- Target youth - programmes need to be aimed at attracting young people to the region and the city of Łódź, focussed on: non-material lures such as cultural events; assistance with transitioning from education to work; providing vocational counselling; education that is adjusted to meet employers' expectations and requirements; practical training; and measures facilitating ones first employment 
(tax deductions and subsidies). The aim of these activities is to discourage youth from emigrating to other regions, particularly the country's capital.

- Health - a high death rate and the worsening health conditions of Łódzkie citizens indicate the need to develop measures for promoting healthy lifestyles, particularly for people in their 20s, 30s, and 40s.

- Ageing population - public action is needed, which is designed to enable the ageing population to live active lives, especially in their retirement years. People in their fifties and sixties should have easy access to health care and to training that will enable them to remain in employment for longer. People over 50 should be recognised as a growing consumer segment, especially for older entrepreneurs and older workers, in order to prolong their economic activity. The creation of local networks of 'surrogate' carers, who can temporarily replace family carers due to illness or leave could also be of assistance.

- The capital of the region - Łódź is the weakest element of the region in terms of mortality, morbidity, fertility and migration attraction. There is simply no possibility of solving the economic and demographic problems of the region without first revitalising the city. 


\section{CHAPTER 1: INTRODUCTION}

The Łódzkie Region in its current configuration (February 2013) was established on 1 January 1999 (Figure 1). It consists of lands that formerly belonged to five different administrative units (Lódzkie, Skierniewickie, Sieradzkie, Piotrkowskie, and Płockie). Because the administrative divisional change for Poland took place before the digitalisation of the majority of records, most of the data relating to the Łódzkie Region dates from the 1990s.

The region was established following an administrative reform in 1999, and it is characterised by a significant cultural homogeneity, due to the fact that between 1919 and 1974 its territory formed an almost unchanging single administrative system, and prior to that, in the $19^{\text {th }}$ century it was part of the Polish Kingdom, under the reign of Russia.

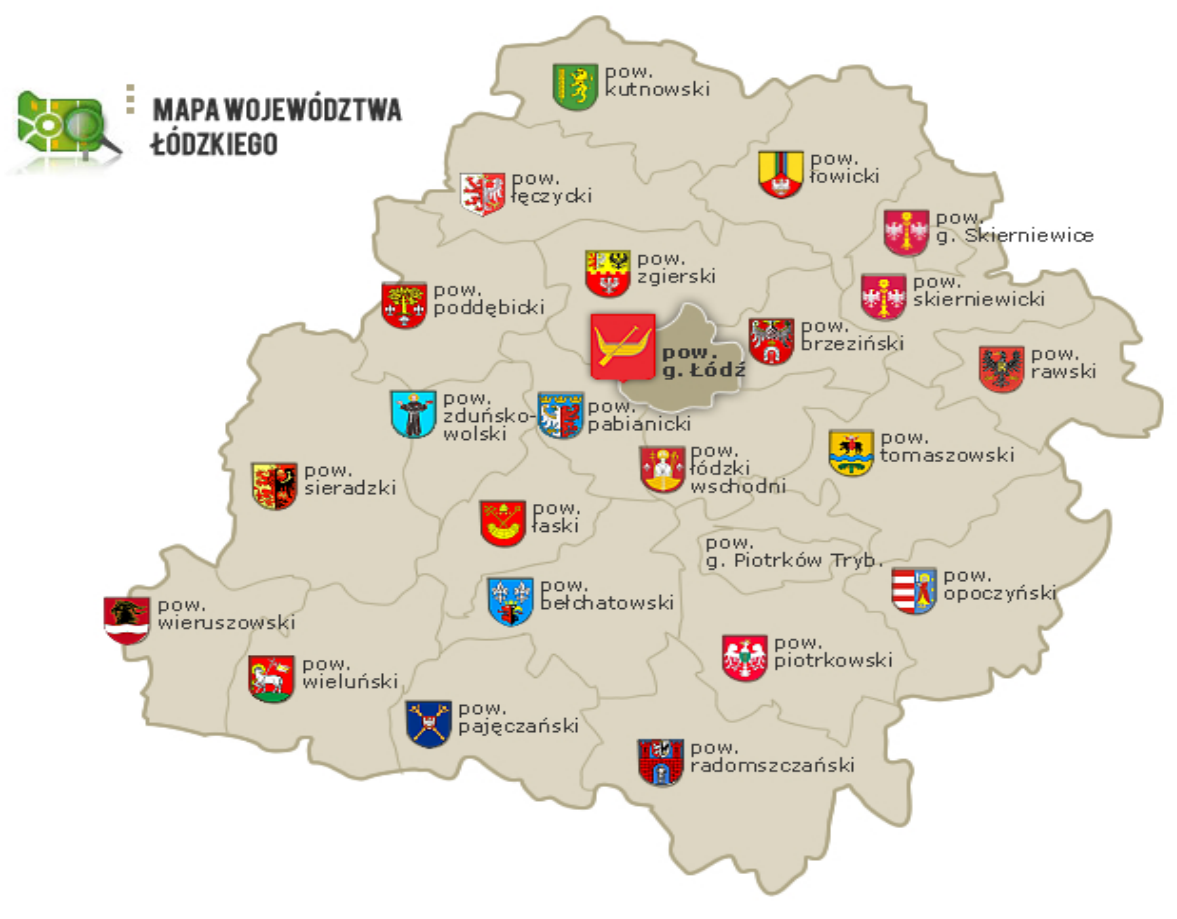

Figure 1 Lódzkie region - administrative division

Source: http://www.lodz.uw.gov.pl/page/1617,mapa-wojewodztwa.html

The Łódzkie region is located in the central part of Poland, with most of the major cities of Poland being within a radius of $200 \mathrm{~km}$, and almost all European capital cities being within $1500 \mathrm{~km}$. The region's location is of crucial importance, because it makes it an attractive location for investors and as a goods distribution centre at the national and European level (important logistics centres are based in the 
region of Stryków and Piotrków Trybunalski). The Łódzkie Region covers an area of $18219 \mathrm{~km}^{2}$, with a population of approximately 2.5 million.

The region is a central transfer and junction area for Poland, having access to major transport routes and technical infrastructure such as pipelines and power lines, as well as being the site of present and future significant junction points. The location of the Lódzkie region for transport and transit concerns is one of its biggest advantages. Road transport plays the most prominent role in the region, its framework being: motorways (A1 and A2); expressways (S-8 and S-14); and primary fast highways, main roads and service roads. Two trans-European transport corridors run through the Łódzkie region, travelling east-west (including the A2 motorway and E20 Railway Main Line) and north-south (including the A1 motorway, the Śląsk-Porty coal primary transport line, and the main line of the Central Railway).

In the following chapters, attention will be paid to the demographic challenges perceived as being threats to the sustainable development of the Łódzkie region. However, the population change should not be seen as being destiny, but rather as a trigger, forcing regional and local authorities to consider how best to use the accessible resources in order to meet these challenges. The following chapters outline the most important and valuable resources available to mobilise to counteract demographic change. 


\section{CHAPTER 2: CHARACTERISTICS OF THE LÓDZKIE REGION}

\subsection{Demographic change $1990-2010$ and forecast}

The population of the region has decreased from 2.688 million in 1995 to 2.534 million in 2010 (Figure 2). Furthermore, in a considerable part of the region, this decrease was occurring much earlier, such as in the north-west communes, where population decline has been in effect since the 1970s, while the capital of the region, the city of Łódź, has been experiencing depopulation since 1989. The most recent forecast of the Central Statistical Office, which is from 2008, suggests that this trend will continue; by 2020, the Eódzkie region's population will be approximately 2.419 million people, while in 2035, it is estimated that the population will decrease to 2.188 million $^{1}$. In the upcoming years, according to Statistics Poland projections for the years 2010-2035, the region's depopulation rate will be one of the highest in Poland. De-urbanisation is expected, due to a rapid decline in the number of inhabitants living in the cities and towns located in the central part of the region. The de-urbanisation will be related to so called suburbanisation, i.e. a concentration of the population in areas surrounding the biggest cities of the region. Public transportation should be developed to enable speedy commuting, and good transportation systems need to be put in place. At the same time, suburbanisation leads to budget problems within cities - people living in the adjacent areas (and paying taxes there) consume many public services produced and financed by the cities' authorities. Tools need to be developed that are designed to share the costs related to producing the services between "centre" and "periphery".

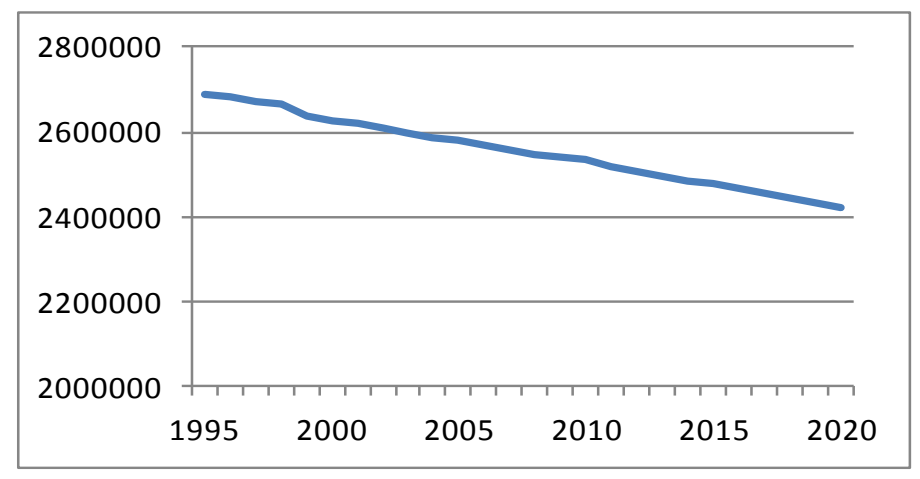

Figure 2 Population living in Lódzkie region, 1995-2010 and projections 2011-2020

Source: Statistics Poland: for the years 1995-2010 http://www.stat.gov.pl/bdl/app/strona.html?p_name=indeks; for the years 2011-2020 http://demografia.stat.gov.pl/bazademografia/Prognoza.aspx

\footnotetext{
${ }^{1}$ Szukalski P., Ludność województwa tódzkiego w perspektywie roku 2035 na tle Polski w świetle prognoz GUS (Population of Lodzkie region up to year 2035 in light of the CSO demographic projection), [w:] P. Szukalski Społeczno-demograficzne wyzwania stojace przed Łodzia $i$ województwem łódzkim (Socio-demographic challenges in Łódź and in Lodzkie region), „Acta Universitatis Lodzensis. Folia Sociologica”, nr 35, Wyd. UŁ, Łódź 2010, 7-33
} 
This depopulation has primarily affected Łódź rather than the region as a whole. While the population was slightly above 850000 at its peak between 1988 and 1989, at the end of 2010, the city population was only 737000 , and projections show that by 2020 the number of citizens will decrease to 671000 and in 2035 to 578000 (Figure 3). Suburbanisation does not compensate for this depopulation, since the region surrounding the Łódź metropolitan area, which covers the four poviats (counties) located around the city, was in 1999 inhabited by 375300 people, and in 2010 by 379000 people, with an observable growth in the country areas.

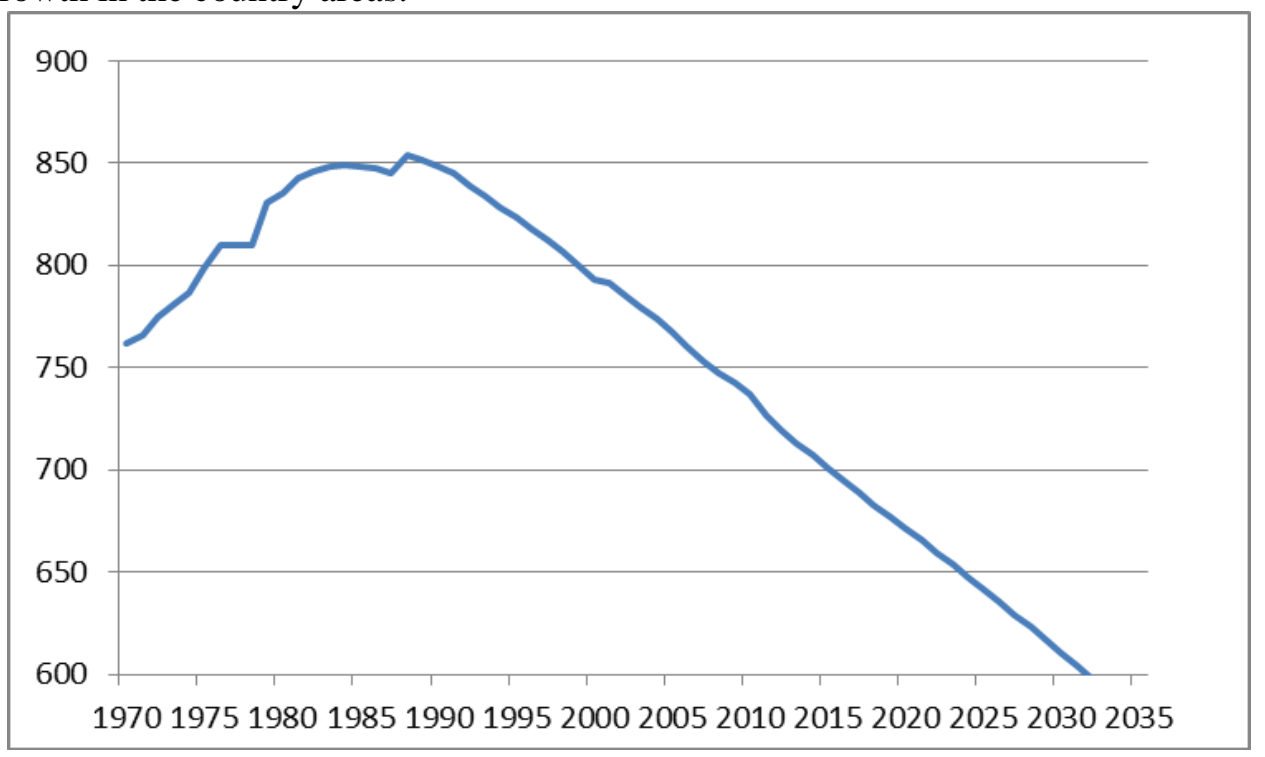

Figure 3 Population living in Lódź, 1970-2030

Source: P. Szukalski, Przyszłość demograficzna Łodzi (The demographic future of Łódź), "Demografia i Gerontologia Społeczna - Biuletyn Informacyjny”, 2011, Nr 2, 2

In the case of the region and the city of Łódź, the reasons for depopulation include both the negative natural increase and the negative migration balance, the former being definitely a more crucial depopulation factor than the latter.

The negative natural increase results from the fact that the fertility rate has for a long time been below the replacement rate, and even below the average fertility rate of Poland as a whole (Figure 4). A particularly low fertility rate has been observed in Łódź since the mid-1980s. The total fertility rate (TFR) has been below 1.5; and since 1995, below 1.25. 


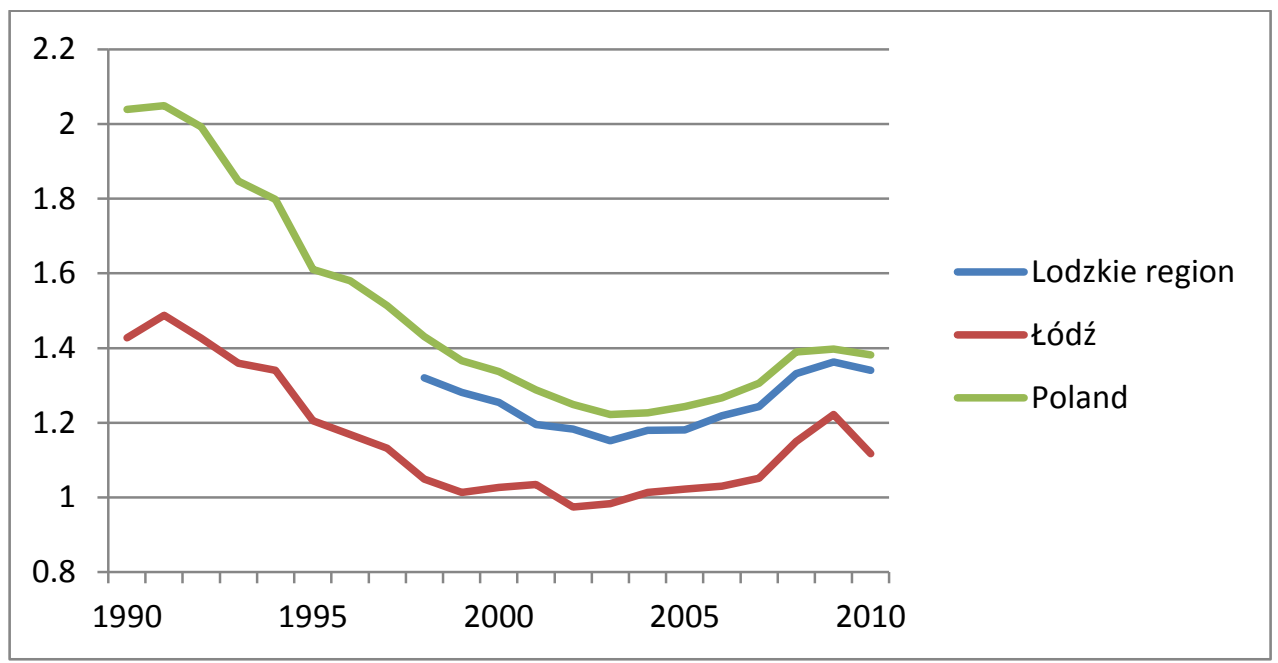

Figure 4 TFR in Lódź and in the Lódzkie region, 1990-2010

Source: CSO data

The low total fertility rate results from lower age-specific fertility rates in almost all the age groups; since 2001, only in the 25 to-29 year age bracket has the fertility rate of the Łódzkie region been somewhat higher than the national average. As a result of this, many of the decisions on whether or not to have children are made at the end of the third decade of life, which is indicated by the fact that in the case of both teenagers and women aged over 35 years, the fertility rate in the study region is significantly lower (approx. 10\%) than the national levels. Thus, it appears that particular emphasis should be placed on those instruments of pronatalistic policy that impact on the willingness of women aged over 30 years to have children. Unemployment rates among females, which exceed the national average, combined with lower remuneration levels, detailed in the next section of this report, undoubtedly effect concerns about stability. A higher frequency of divorces in the region, in Łódź in particular, is another factor worth considering (in 2010, out of 1000 newly wedded couples in each area, 268.5 divorced in Poland, 294 in the Łódzkie region, and 435.4 in Łódź).

Territorial governments increasingly often perceive the low fertility rate as a threat to long-term development, which is why several cities in the region (Skierniewice, Radomsko, Łowicz and Tomaszów Mazowiecki) have implemented the "Large Family Chart" (Karta dużej rodziny) initiative, which enables all families bringing up at least three children to purchase services provided by the territorial government entities, such as access to local public transport, swimming pools, clubs and museums, at lower prices or even for free. The initiative was considered as being both affordable (in that the cost of the relief is lower than paying additional allowances) and socially preferable (only consumption of socially accepted goods is supported). Few other local authorities have considered such a plan, because times of financial constraint, do not favour such a solution.

The demographic specificity of the Łódzkie region is mostly related to having the highest mortality rate in the country, resulting in a particularly low life expectancy (Figure 5). Although the mortality rate has successively lowered in the last two decades, the pace for this has been slower than the national average. The situation is most unfavourable in Łódź, where life expectancy is even lower than in the rest of the region. What makes Łódź distinctive is that this means it is the only large city, particularly the capital of a region, whose inhabitants on average live for shorter periods than people in the surrounding regions. 


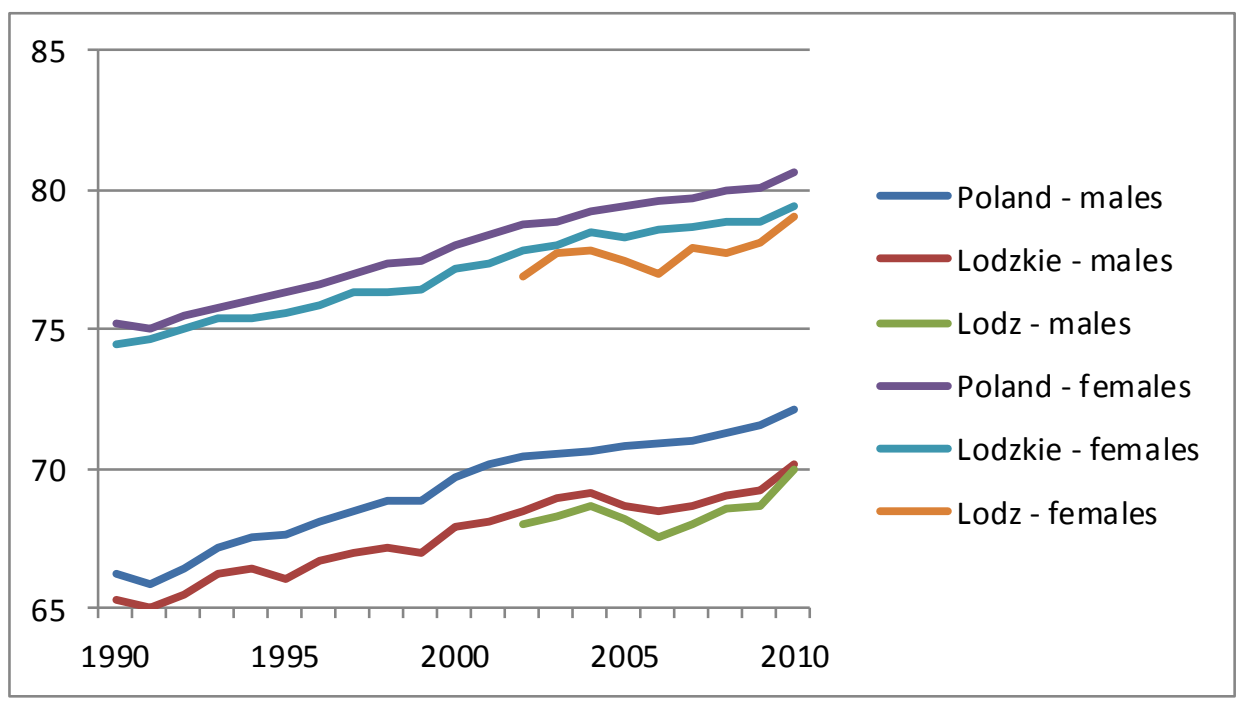

Figure 5 Life expectancy by sex in Lódź and the Lódzkie region, 1990-2010 Source: Statistics Poland data

The high mortality rate results are mostly among people between the ages of 20-50 and due to cardiovascular diseases, rates which are $40-80 \%$ higher than they are in the rest of Poland (Figure 6). However, this high mortality rate can also be connected to results regarding the assessment of quality of life, which indicate that the inhabitants of the Łódzkie region, together with the inhabitants of the Lublin region, are least satisfied with their living conditions and show the lowest levels of optimism when considering their future prospects ${ }^{2}$. Cardiovascular mortality is primarily the result of man-made diseases, so it is recommended that public authorities increase inhabitants' awareness of cardiovascular diseases and promote healthier lifestyles.

\footnotetext{
${ }^{2}$ Panek T., Wielowymiarowy wymiar ubóstwa w Polsce w ujęciu regionalnym, "Wiadomości Statystyczne" 2010, nr 2, 18-37
} 


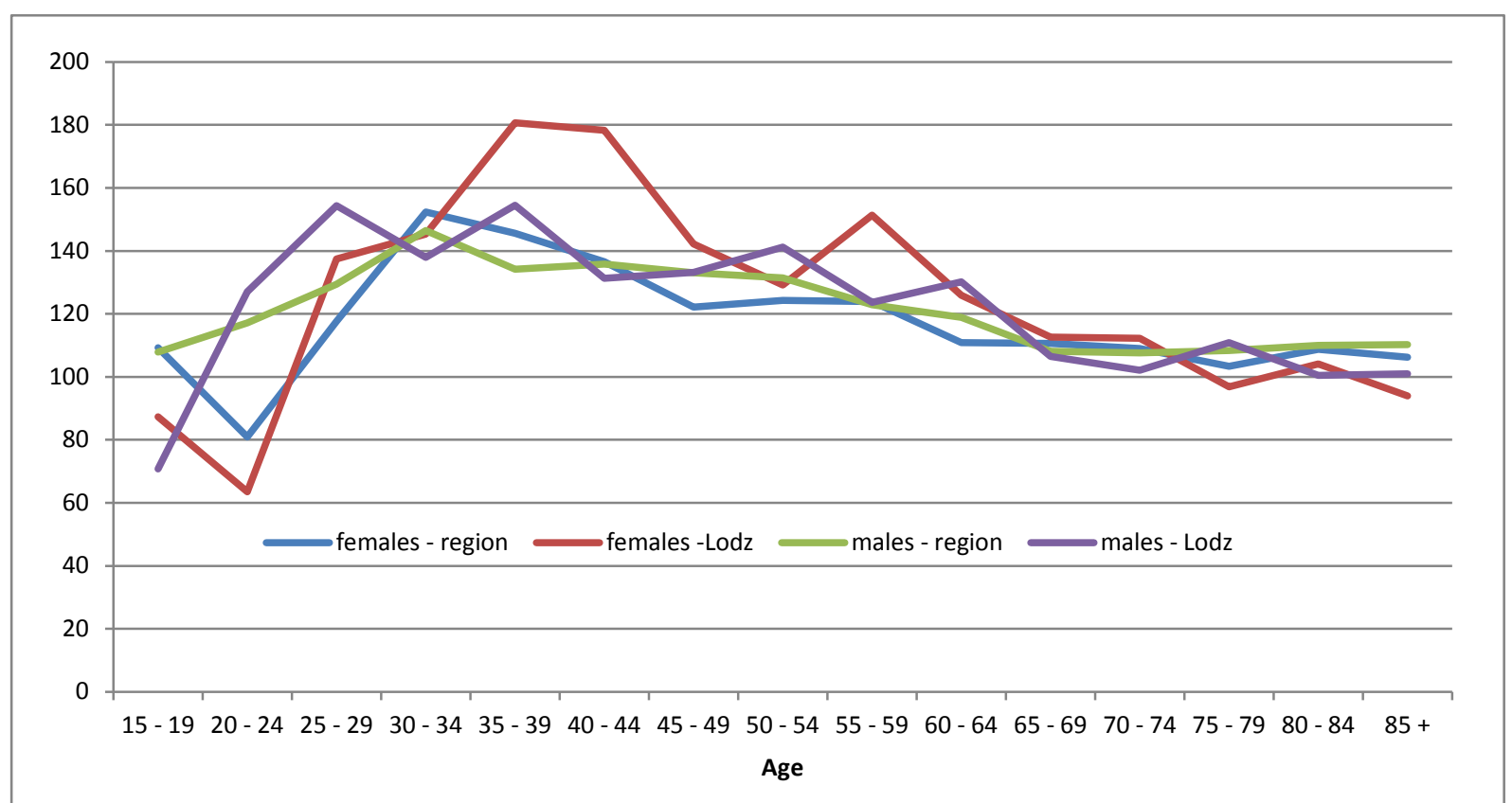

Figure 6 Age-specific mortality rates among male and female inhabitants of Lódź and the Lódzkie region in comparison with Poland in 2010

Source: calculations based on data from the Central Statistical Office

Considering the reasons for the high death rate in the region, it should be emphasised that in the first decade of the 20th century, the region was characterised by having the highest or one of the highest death rates due to liver and digestive system disease, pneumonia, respiratory system diseases, and traffic accidents. The death rate related to suicides was also at a higher level than the national average, but was relatively stable within its own parameters. ${ }^{3}$ The majority of the above mentioned causes of death are related to lifestyle. In the case of Łódź, the reasons for these high rates include low educational attainment levels of the population, a low quality of natural and social environments and, particularly in central districts, which were built at the turn of the $19^{\text {th }}$ and $20^{\text {th }}$ centuries, a low quality of living arrangements.

The death rate in the first year of life was much lower than the overall death rate, and was below the national average (in 2010, it represented the lowest rate on the national scale), which was mainly due to accessibility to specialised medical care. ${ }^{4}$ This demonstrates that medical care should be treated holistically, whereby education of patients together with specialised care and health promotion can help counteract the current circumstances. Thus, the elements of public health should focus not only on the beginning of life, but also on the whole life-cycle in order to ameliorate the health status of the population.

The Łódzkie region has also been characterised by a negative migration rate, at least since 1995. The problem has always afflicted country regions but, since 2001, it has also been experienced in urban areas. Since 1992, the city of Łódź has experienced a negative migration balance that largely results from the proximity to Warsaw. Twice as high a remuneration rate in the capital of the country means that many inhabitants of the Łódzkie region are attracted there, to its eastern part in particular, since it borders directly on the Masovia Region. The public transport system is full of people commuting to Warsaw in order to work or to study, who later, having found stable employment, change their place of residence. The proximity to Warsaw also has a negative effect on the development of Łódź, which suffers from an outflow

\footnotetext{
${ }^{3}$ B. Wojtyniak, P. Goryński (ed.), Sytuacja zdrowotna ludności Polski, NIZP -PZH, Warsaw 2008

4 The best and largest diagnostic and medical care centre specialising in gynaecology and obstetrics, Centrum Zdrowia Matki-Polki Hospital, is located in Łódź.
} 
of the best-educated and younger inhabitants and which thus loses many potential students, who choose to pursue their education in a city that offers better conditions for the development of a professional career. There is a need to create new and stable professional opportunities for young people. If this requisite cannot be met, the remaining solution is the development of suitable public transportation that will enable daily commuting to the more attractive regions in order to retain taxpayers and consumers.

As the result of a preference to live in rural areas and higher total fertility rates of the rural population, de-urbanisation has been observed in the region i.e. an increasingly smaller proportion of the population lives in the regional cities (for instance, in 1998, 64.9\% lived in the regional cities, while in 2010, this dropped to 64\%). Suburbanisation, or the concentration of the population in the areas surrounding larger cities in the region, causes numerous negative consequences for the cities, a decline in fiscal revenue in particular (due to the government transferring some of the cities' income tax revenues to the territorial governments) and citizens earning incomes higher than the average moving to suburban areas. At the same time, this process adds to the increased ageing rates of the urban population, whose needs are met by local social policy institutions, which are funded by city budgets. A large number of residents of the suburbs work in the cities, therefore, expect that the city governments will ensure certain social services are available (such as nurseries and schools), which then involves additional allocation of costs to the city governments. Some financial mechanisms should be enacted to transfer tax revenues from "richer" areas of in-flow to "poorer" areas of out-flow in order to compensate for the cost of public services provided to migrants who are, in the majority, working in bigger cities and consuming services produced there.

The Łódzkie region is considerably diverse in terms of its population problems. Those areas best situated are in the former Łowicz Principality (the north-eastern part of the region) and in the south-west part of the region; while the worst areas are in Łódź, in the communes around the city and in the north-west area of the region. As a result, in the early 20th century, Łódź was among 5 poviats (counties) characterised by having the largest decline in population size on a national scale. ${ }^{5}$

Between 1995 and 2010, as the result of decreasing population size, population density in the region also fell, from 147 to 139 people per $\mathrm{km}^{2}$. This figure, however, was still above the average for Poland (122 people per $\mathrm{km}^{2}$ ). A significant territorial differentiation in the population density was recorded: in rural areas it was only 53 people per $\mathrm{km}^{2}$; while in urban areas, it reached 1424 people per $\mathrm{km}^{2}$ (2 514 in Łódź). In general, the lowest density was recorded in poviats adjacent to other regions, while the highest levels are to be found in the areas adjacent to the capital city of the region.

The region is characterised by a high rate of feminisation - in previous years, the ratio between males and females was 100 males to 110 females (the average for Poland is 107), whereas a significantly higher rate of feminisation has been observed in Łódź (120), and in the municipalities in the central part of the region in particular. A higher rate of feminisation in the Łódzkie region is recorded among people aged $40+$, while for the population of Poland, it is primarily found within people aged 50+. The main cause of the high rate of feminisation is related to high male mortality rates, resulting in extremely significant differences between male and female life expectancies.

As a result of the decrease in population, the Łódzkie region is experiencing an accelerated ageing of the population; in 1990, the percentage of people at the age of 65+ was 12.6\%; in 2000 it increased to 14.4\%, and by 2010 it was 15\% (Figure 7). The statistical projections of the Central Statistical Office indicate that this proportion will rise to the level of $20.4 \%$ in 2020 , and $25 \%$ by 2035 . At the same time, the so-called double ageing problem will increase, with the percentage of people aged $80+$ expected

\footnotetext{
${ }^{5}$ Rządowa Rada Ludnościowa (Government Population Council), Sytuacja demograficzna Polski. Raport 2010-2011, Warszawa 2011, pp. 220-221
} 
to rise from the current $4 \%$ to $4.4 \%$ in 2020 and to $8 \%$ in 2035 . The ageing of the population is particularly visible in the capital of the region, where in 2010, people of age 65+ constituted $17.2 \%$ of the population and those aged $80+$ was $4.8 \%$, while the forecasts indicate that in 2020 these proportions will rise to $24 \%$ and 5.3\% respectively and in 2035 it is anticipated to increase to $27.3 \%$ and $9.9 \%$.

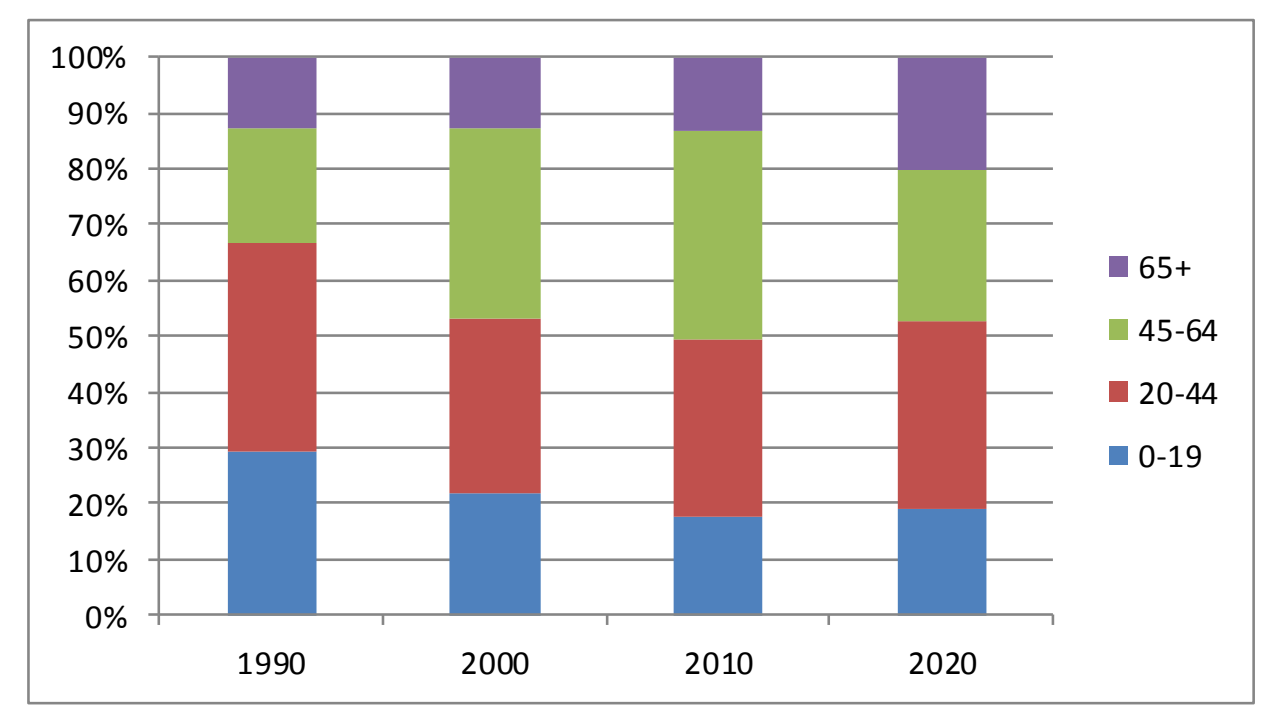

Figure 7 Age distribution of the Lódzkie region's population, 1990-2020 Source: calculations based on CSO data

The extent and pace of the population ageing rates enhance social challenges; the double ageing issue particularly affects social services, increasing demands on medical services, social assistance, and nursing. Changing family patterns, such as less numbers of offspring and siblings, and more divorces, result in reduced family support, bringing the need for public support to the fore. Public policy should therefore be focused on meeting two aims: providing the elderly with some basic services; and enabling self-sufficiency, or at least basic levels of autonomy. In the Polish case, the first aim is treated as being more important, but the policy at the national and especially at the regional level should be redesigned to focus on the second dimension - the elderly's self-sufficiency.

\subsection{Socio-economic characteristics and labour markets}

The following factors have influenced the current economic structure of the Łódzkie region:

- Historically shaped, light industry monoculture within the territory of the Łódź City Agglomeration;

- Agricultural characteristics of a significant part of the Łódzkie region;

- The region's location within an area rich in brown coal and natural building materials;

- High academic, cultural and service potential concentrated in the capital city of the region;

- Poland's economic transformation - implementation of market economy principles and business ownership transformations;

- Polish economy entering the post-industrial phase;

- Establishing the Łódź Special Economic Zone within the Łódzkie region; 
- Foreign investments in various sectors of the economy; and

- The favourable geographic and transport-related location of the Łódzkie region.

The employment structure within the specific economic sectors of the Łódzkie region reflects the economic structure of the region to a great extent. In comparison to the average indicators for Poland, the Łódzkie region is characterised by employment in the industry and agriculture sectors, which is higher than Poland's national average, while employment in the services sectors, market services in particular, is lower than the national average - refer Table 1.

Table 1 Structure of employment by economic sector, 2010

\begin{tabular}{lcc}
\hline Economic Sector & Lódzkie & Poland \\
Agricultural sector & $13.0 \%$ & $12.8 \%$ \\
Industrial sector & $31.9 \%$ & $30.2 \%$ \\
Services sector & $55.0 \%$ & $56.9 \%$ \\
\hline
\end{tabular}

Source: Godlewska-Majkowska H., Zarębski P., Atrakcyjność inwestycyjna regionów 2011. Raport syntetyczny, (Investment attractivity of regions, 2011), Warszawa 2011, www.paiz.gov.pl/files/?id_plik=16734

The last decade was a period of profound change in employment structures (Figure 8): a decline in the importance of agriculture was observed; the slight increase in employment within the industry sector is related to the discovery of Łódzkie as a centrally located region with excellent transportation to other parts of the country and to the other CEE countries. Increases in the number of people employed in the services economy is, at least in part, a consequence of treating Łódź as one of the best places in which to locate outsourcing services. These changes should be supported by three different means: policy aimed at development of infrastructure; development of the skills needed for business process outsourcing (BPO), especially language competencies focused on less popular languages (i.e. languages other than English, German, or French); and changing the image of the regional capital as being an unattractive place for potential investors and for young, educated employees.

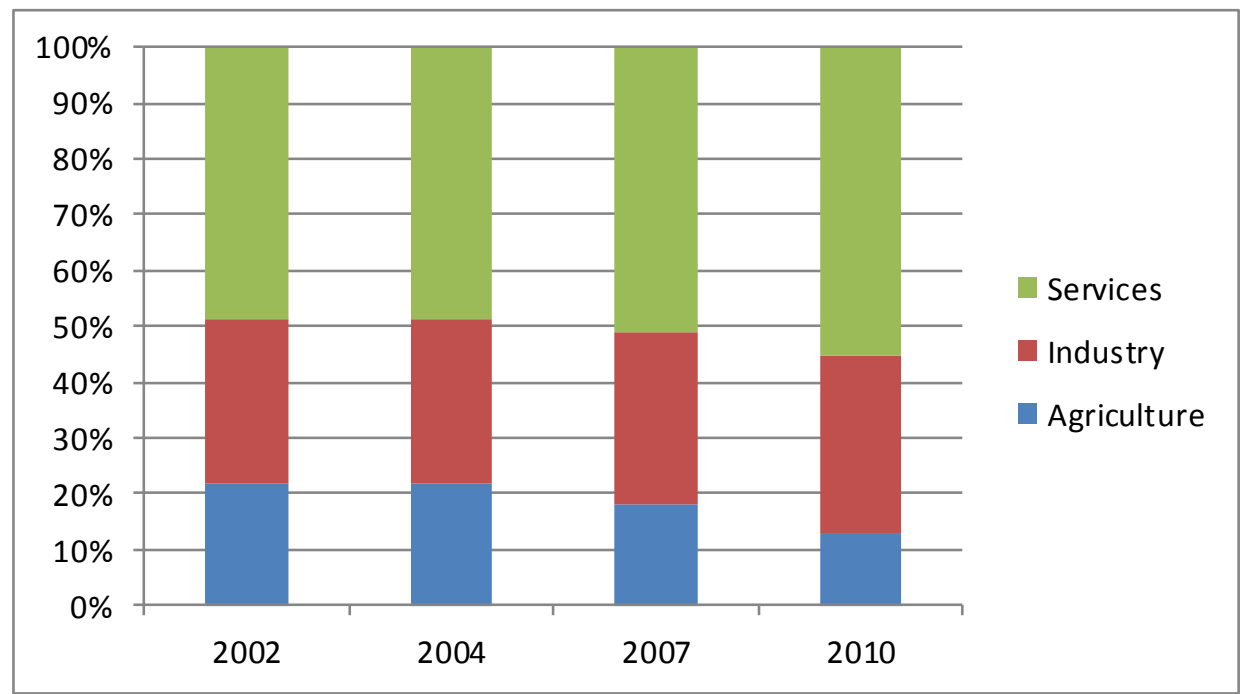

Figure 8 Changes in the structure of employment by economic sectors, 2002-2010

Source: Rynek pracy w województwie tódzkim. Specyfika i uwarunkowania (Labour market in Lódzkie region. Specificity and determinants), Łódź, 2006, www.old.asm-poland.com.pl/diagnozazawodow/publikacja.pdf, Analiza sytuacji społeczno-gospodarczej województwa lódzkiego (Socio-economic situation of the Łódzkie region), Łódź 2010, www.si.lodzkie.pl/wcentrumuwagi/diagnoza_wl_2010.pdf; Godlewska-Majkowska H., Zarębski P., 
Atrakcyjność inwestycyjna regionów 2011. Raport syntetyczny (Investment attractiveness of regions, 2011. Synthetic report), Warszawa 2011, www.paiz.gov.pl/files/?id_plik=16734

Another measurement used to assess the economic structure of the Łódzkie region is the share specific sectors of the regional economy play in the Gross Value Added. In 2009, the highest Gross Value Added (GVA), of approximately $58.5 \%$, was created by the services sector, which employs $55 \%$ of the total number of workers. The agricultural sector, which employs over $13 \%$ of the total number of workers, provided only $4.9 \%$ of the GVA, while the industrial sector (industry and construction), employing $31 \%$ of the workers created $36.6 \%$ of the GVA in the Łódzkie region ${ }^{6}$.

As of 31 December 2010, the number of workers in the Łódzkie region reached 943200 persons, i.e. $5 \%$ more than it was in 2005. The workforce in the Lódzkie region constituted $6.8 \%$ of the total number of workers in Poland (13 788 200). In 2010, most of the workforce was concentrated in the following areas: industrial processing - 20.8\%; trade - repairs of motor vehicles $-15.5 \%$; and education 7.3\%. Between 1999 and 2009, the most dynamic changes in the number of people employed, by economic section, were observed in: health and social assistance (declined by $26.2 \%)$; industrial processing (-18\%); immobility services for employers (increased by 56\%); hotels and restaurants (+ 28.2\%); and education (+ $16 \%)^{7}$.

By the end of December 2010, the registered unemployment rate in the Łódzkie region reached $12.2 \%$, which was, however, below the national average (12.4\%). The intensity of unemployment rates within the Łódzkie region varied depending on individual poviats (counties) ${ }^{8}$. In 2010, the variations in the unemployment rate ranged between $7.8 \%$ in the Skierniewice poviat (its closeness to Warsaw helped to lower the unemployment rate to so low a level), and $17.7 \%$ in the Tomaszów Mazowiecki poviat (the result of the collapse of the chemical works located in the poviat). However, it should be highlighted that in the case of the Tomaszów, Kutno and Łaski poviats, there has been a high and long-term unemployment rate recorded for the past several years, which indicates structural unemployment. Overall, in the 1990s the unemployment rate in the region was significantly above the national average, while the 2000s were a period of relative improvement in the region and in the majority of poviats.

Female residents of the Łódzkie Region are characterised by a higher level of vocational activity in comparison to Poland as a whole. At the same time, in the context of this observation, there are no differences between unemployment rates of females and males, and in particular years, women were in a better situation in terms of unemployment ${ }^{9}$. However, some surveys performed recently indicate that the regional labour market differently grades vocational experience and education in terms of gender - each year of education raises the salary level of females by $3.3 \%$, but for males it is raised by $4.2 \%$. At the same

\footnotetext{
${ }^{6}$ Statistical Office, Katowice. Produkt Krajowy Brutto. Rachunki regionalne w 2009 r., Katowice 2011

${ }^{7}$ Kwiatkowska W., Poziom oraz struktura sektorowa i zawodowa popytu na pracę $w$ województwie tódzkim i jego powiatach w latach 1999-2009, [in:] E. Kwiatkowski (ed.), Popytowe i podażowe aspekty kapitatu ludzkiego $w$ regionie łódzkim, Wyd. Uniwersytetu Łódzkiego, Łódź 2012

8 Statistical Office in Łódź, Rynek pracy $w$ województwie łódzkim $w$ latach 2005-2010, Łódź 2011, http://www.stat.gov.pl/lodz/51_PLK_HTML.htm

9 A great majority of respondents from the Łódzkie Region surveyed in 2009 declared that females had a smaller chance of finding employment, where males holding higher education qualifications stated that gender is of no importance in searching for work - see Malinowska E., Dzwonkowska-Godula K., Świadomość społecznych nierówności ptci, [in:] P. Starosta (ed.), Zróżnicowanie zasobów kapitału ludzkiego i społecznego w regionie łódzkim, Wydawnictwo Uniwersytetu Łódzkiego, Łódź 2012
} 
time, each year of employment contributes to an increase in income for females of $4.7 \%$, which is a greater increase than that for males (3.8\%). ${ }^{10}$

In comparison to the national average, the Lódzkie region is characterised by a slightly higher share of self-employed people, where males dominate (in 2009, 63.4\% of the total number of selfemployed people in the region were men). This situation results from the fact that a large number of selfemployed people are farmers: in 2009, 52.8\% of Łódzkie self-employed people worked in the agriculture, forestry and fisheries sector; $16.8 \%$ were in the motor vehicles trade and repairs sector; $8.1 \%$ in construction; $5 \%$ in industrial processing; and $4 \%$ in transport and warehouse management. A significant group of the working population in the reference period was at the so-called 'immobile' working age: $53.1 \%$ of the self-employed were older than 45 years; while only $19 \%$ of the self-employed were under 35 years of age. The older self-employed were characterised by a lower education level than the labour force at the equivalent age in general (to a great extent they were farmers), while a great majority of people under 35 years of age held at least secondary education levels ${ }^{11}$. The above-mentioned characteristics underlie the importance of life-long learning, especially for people in their thirties and forties, who have to keep pace with the profound digitalisation of life and professions.

The economic structure of the Łódzkie region is characterised by a spatial concentration of fixed assets ( productive assets, resources used to generate production) in two poviats. Łódź township poviat and the Bełchatowski poviat hold fixed assets constituting $62 \%$ of the total fixed assets of all the enterprises situated within the Łódzkie region, and provide $45 \%$ of the total industrial production in the region.

Aside from these two industrialised districts, until recently, industry had a monoculture-based structure, but the following industrial centres have developed in the Łódzkie region, which are characterised by their more diversified branches: Radomsko; Piotrków Trybunalski; and Kutno.

As a result of the above-mentioned concentration of fixed assets, the level of remuneration also varies, which is reflected in the productivity level. Salaries exceeding the average value in the region (3066.02 PLN in 2010) were recorded in only four poviats: Bełchatów (4628.24 PLN); Piotrków Trybunalski (3297.76 PLN); Łódź (3243.15 PLN); and Poddębice (3087.08 PLN). The lowest remunerations were recorded in Wieluń (2458.98 PLN) and Brzeziny (2379.47 PLN) poviats. ${ }^{12}$

Strategic sectors, which receive various types of support from the regional government and regional business environment institutions, provide the driving force for the regional economy and a solid base from which to strengthen competitive potential. At present, both the so-called traditional branches (textiles and clothing, power industry, and fruit and vegetable sector), and branches with development potential (new technologies, mechatronics and IT/ICT), are undergoing energetic development in the region. Łódzkie is one of the three Polish regions that are predestined to become bioregions, due in Łódzkie's case to its particularly promising development within the biotechnology sector. A potential obstacle to this progress is a lack of co-operation between academia and industry, and fragmentation of regional priorities by which public resources are distributed. The best solution to this problem could be to concentrate public support on a few of the most promising areas.

\footnotetext{
${ }^{10}$ Kubiak P., Równość kobiet $i$ mężczyzn na rynku pracy $w$ województwie łódzkim i jego powiatach, [in:] E. Kwiatkowski (ed.), Popytowe $i$ podażowe aspekty kapitału ludzkiego $w$ regionie tódzkim, Wydawnictwo Uniwersytetu Łódzkiego, Łódź 2012

${ }^{11}$ Kaczorowski P., Samozatrudnienie jako forma rozwoju przedsiębiorczości w województwie tódzkim - ocena dotychczasowego stanu, bariery i perspektywy, [in:] E. Kwiatkowski (ed.), Popytowe i podażowe aspekty kapitału ludzkiego w regionie tódzkim, Wydawnictwo Uniwersytetu Łódzkiego, Łódź 2012

${ }^{12}$ Statistical Office in Łódź, Rynek pracy $w$ województwie tódzkim w latach 2005-2010, Łódź 2011
} 
The regional government aspires to turn Łódzkie into a site attractive to investors, which will provide them with unobstructed development. Measures implemented include: support to clusters; trilateral co-operation among business, science, and administration; technology transfer; international business cooperation; and minimising barriers to entrepreneurship.

Approximately 200000 economic entities are located in the Łódzkie region. A great majority of these businesses belong to the small and medium enterprises (SME) sector. More than $90 \%$ of these companies are privately owned, which indicates a high degree of entrepreneurship within the region's population ${ }^{13}$. Over one-third of all the companies operating in Łódzkie operate in the sector of trade. The next highest sectors comprise production enterprises, real estate services, and construction and transport road transport in particular. Companies and production plants mainly deal with manufacturing apparel, fabrics, foods, beverages, furniture, finished metal products, and leather tanning and dying. In addition to the strategic location of the region and its industrial traditions, the regional raw materials and agricultural potential represent other key factors for economic development in the Lódzkie region. Based on brown coal deposits, the Bełchatowski Basin developments are occurring in the south, while the northern part of the region concentrates on its rich resources of geothermal waters. Kutno, Łęczyca and Łowicz poviats in the northern part of the region have also specialised in agricultural and food production, while the Sieradz district, which is located in the west, focuses on its timber and furniture industry.

The pharmaceutical industry, including wholesale production of pharmaceuticals and herbal medicines, is an industry within the Łódzkie region which is characterised by strong development-based dynamics. Enterprises operating within the household appliances sector are also concentrated in Lódzkie, because of the availability of highly qualified staff and specialised sub-contractors ${ }^{14}$.

The Łódzkie region is among the leaders in manufacturing of many products, including: hosiery $65 \%$ of the domestic production; brown coal $-58.4 \%$; hand-made and garden glass $-51.3 \%$; tar board 45.4\%; cotton fabrics - 40.7\%; towel fabrics and velvet $-38.4 \%$; and blankets and rugs $-32.1 \%$. The share in production of wool and synthetic fabrics, underwear, overcoats and fabric-made clothes as well as electrical energy is also significant $(20.4 \%)^{15}$.

Regional and local authorities continue to search for and encourage new economic sectors, whose development could provide new jobs. Incentives to undertake such measures vary, but activities implemented by two municipalities, Kleszczów and Uniejów, may serve as examples. In the case of Kleszczów, awareness of the fact that within several years the large income currently resulting from charges paid by brown coal mining will expire is an incentive to the municipality authority (Box 1). In the case of Uniejów, momentum is provided by the availability of geothermal springs, which have been used for 10 years, and which are characterised by their medicinal value (Box 2).

\section{Box 1 Kleszczów Municipality}

Kleszczów Municipality is the most industrialised portion of the Łódzkie region. The Bełchatów Brown Coal Mine and Bełchatów Power Plant are among the largest companies in Poland. The power plant has a 4440 megawatt capacity. As a result of having these two large enterprises located within this single municipality, it generates one of the highest income levels per capita in Poland.

However, Kleszczów authorities realise that in several years' time, the brown coal deposits found within this municipality's territory will have been exhausted. Thus, in order to strengthen Kleszczów’s economic

\footnotetext{
${ }^{13}$ Dorożyński T., Urbaniak W., Rola jednostek samorządu terytorialnego we wspieraniu inwestorów zagranicznych w województwie tódzkim, Łódź 2011, www.biz.uni.lodz.pl/?dl_id=60

${ }^{14} \mathrm{http}: / /$ www.forum.lodzkie.pl/pl/Region_lodzki/

${ }^{15}$ http://www.forum.lodzkie.pl/pl/Region_lodzki/
} 
development, in the late 1990s its local government decided to develop new investment lands. Kleszczów Industrial Zones attracted interest from many domestic and foreign investors, and entrepreneurs from such countries as Germany, Finland, Austria, France, the Netherlands, Italy, Portugal, Switzerland and Spain located their businesses in this municipality.

Next to mining and power generation, the economic characteristics of Kleszczów municipality are increasingly shaped by small and medium-sized enterprises. One of the first industrial zones in Poland was established in this municipality. The Kleszczów Municipality Development Foundation and "Arreks" S.A. Regional Development Agency, i.e. the so-called business environment institutions, developed and launched a programme of actions to support business start-ups.

In order to be able to influence in real terms the price of communal services offered (an important element in the operating costs of many companies), the municipality has decided to retain control of the gas, telecommunications and power supply networks it has constructed. This approach provides investors with stable of pricing policies for communal services, and at the same time, the municipality is able to earn additional budget revenues due to the lease of municipality properties by utility providers.

The main objective of the municipality's aspirations to attract new investors is to create new jobs for its residents and provide new sources of income for the municipality budget.

Local government, with the support of the above-mentioned foundation and agency, uses various incentives to develop private entrepreneurship of the municipality's population, including:

- $\quad$ organisation of free-of-charge training to enhance qualifications of staff;

- $\quad$ providing comprehensive information on opportunities to establish small and medium-sized enterprises, and basic principles of their operation (organisational, legal, advisory and consulting assistance);

- $\quad$ providing credit guarantees and loans to business start-ups; and

- $\quad$ providing space in Kleszczów Enterprise Incubators on preferential terms to start business activity.

Additionally, a tourist and sports centre, one of the largest leisure and recreation centres in Poland, extends into the forests surrounding the mine and power plant.

Source: www.kleszczow.pl/

\section{Box 2 The town of Uniejów}

The town of Uniejów is situated in the north-western part of the Łódzkie region, on the Warta river. It has a population of 3200 persons and a surface area of $129 \mathrm{~km}^{2}$, including the Uniejów municipality. This district holds an area which is typically agricultural in nature. In the 1970s, springs of hot water with medicinal properties were discovered. In the late 1990s, the municipality decided to use available technologies to access the geothermal waters in order to use them as a source of energy as well as a tourist attraction.

The “Geotermia Uniejów” Sp. z o.o. Company was established in 1999 for the purpose of economic exploitation of the geothermal waters for the heat engineering sector. Delivery of ecologically clean geothermal heat to residents commenced in the winter season of 2000/2001. The Regional Fund for Environmental Protection and Water Management in Łódź co-financed construction of the heating plant using the heat of the geothermal waters and peak oil boilerhouse. Exploitation of geothermal water for heating purposes occurs within a closed system. Water is extracted at the temperature of $68^{\circ} \mathrm{C}$, and once it loses heat, it is then cooled down to $40-45^{\circ} \mathrm{C}$ and redirected to the same water-bearing layer. The geothermal heating network was connected to public utility buildings, such as a school, teachers' home, nursery, Municipality Culture Centre, church, the offices of the "Geotermia Uniejów" Spółka z o.o. company, medical care centre, pharmacy, and communal and co-operative blocks, as well as family homes in two residential districts. Approximately 170 connections were provided.

The second stage of the activities of the local authorities involved construction of the "Termy Uniejów" (Uniejów Hot Springs), a therapeutic and recreational centre. The city obtained funds for its implementation from the European Fund for Regional Development. An open swimming pool complex and a changing room 
facility were constructed as part of the project. These were followed by a catering facility comprising three restaurants and a cafe. A castle, with a tower housing a museum, was erected in close proximity to the pools. The outdoor swimming pools are functionally connected with the indoor ones, which are supplied with medicinal thermal brine. Uniejów thermal brine is used to treat diseases, rheumatoid problems in particular, as well as degenerative changes to joints, orthopaedic and traumatic conditions and post-surgery conditions, problems with motor organs, skin, ailments of the nose, ear, pharynx and larynx, neuralgias, disc lesions and neuroses.

The hot springs are already very popular - more than 20000 people visit every year. Their popularity partly results from the fact that in the region there is a deficit of spa towns (there is no spa town in the Lódzkie region). Currently, the existing thermal and swimming pool complex is being extended, with new indoor and outdoor swimming pools, and a health and beauty complex. The land is also being developed and necessary technical equipment constructed, as well as the tourist infrastructure being extended, with new catering and accommodation facilities.

Source: www.geotermia-uniejow.pl/; www.pnec.org.pl/smart/pdf/uniejow.pdf

The gross national product (GNP) per capita rate in the Łódzkie region is slightly lower than the national GNP per capita (91.3\% of the average in 2009), which translates into lower average wages (PLN 3002 as compared to the country's average of PLN 3 199, i.e. lower by 4.8\%), and lower mean retirement benefits, which are below the average (PLN 1582 as compared to PLN 1698 in 2010, which is 6.8\% lower). The level of income has a direct effect on the level of need satisfaction, which, according to the research on self-assessment, is one of the lowest in Poland ${ }^{16}$. The GNP rate also influences the options available to the regional and local authorities to solve various crucial problems that have been troubling the region due to its considerable diversity in terms of the level of remuneration and infrastructure development. Cities with poviat rights ${ }^{17}$, as well as Bełchatów and Skierniewice generally show the highest standards of living, while the south and the north-west parts of the region have the lowest standards. The region has one of the smallest sub-regional differences in GDP. The most visible dissimilarity - in comparison to the other regions - is the weakness of Łódź in terms of its GDP and population incomes. If Lódź's GDP per capita were equal to the average from the other Polish biggest cities, the region could match the national average. Once again, the weakness of the region is anchored in the weakness of its capital. As a result, special attention should be paid to revitalising Łódź, as the heart of the region.

Development of the social economy in the region is in its initial stage, and is driven by European Social Fund assistance. According to the experts who analysed development of the social economy in 2012, the regional authorities should consider the fact that in the next EU programming period (20142020) a significant emphasis will be placed, and significant funding contributed, to this sector's economy, and this should therefore be incorporated into the regional development strategy, which requires expansion of its timeframes to at least $2020^{18}$.

\footnotetext{
${ }^{16}$ Urząd Statystyczny w Katowicach, Produkt krajowy brutto - Rachunki regionalne w 2009 r., Katowice 2011, http://www.stat.gov.pl/gus/5840_3594_PLK_HTML.htm

${ }^{17}$ Regions are divided into two types of lower administrative units - poviats (local self-governments responsible for roads, secondary education, hospitals, and others social services exceeding municipalities' tasks) and cities with poviat rights, which are cities with populations of at least 50 thousand, having the same responsibilities and available instruments as poviats.

${ }^{18}$ Rekomendacje dla ekonomii społecznej w regionie tódzkim (cz. 1). Wnioski z panelu ekspertów, report from the „Społecznie znaczy ekonomicznie - kontynuacja” Project, Łódź, 2012
} 


\section{CHAPTER 3: OLDER WORKERS: SILVER ECONOMY AND WHITE ECONOMY}

Older workers. Despite the above-mentioned process of the ageing of the population, the number of working-age people in the last decade has remained roughly unchanged. This is because the participation levels of young people have decreased and the percentage of people at working age has risen slightly. However, the labour force has still been ageing, with the percentage of people at the so-called "immobile" working age of $45+$ increasing.

Focusing exclusively on people of $50^{+}$, the number of professionally active people increased between 1995 and 2010 (apart from the 1999-2000 period); up from 236000 to 336000 , which is the result of the post-war population boom generation reaching this age. At the same time, the number of employed people of that age increased from 221000 to 308 000, while the number of unemployed rose from 15000 to 24000 (although it should be noted that at the beginning of the 2010s the number of unemployed of this age reached $41000-46000$ ).

The employment rate among people of the age of 50+ in the period 1995-2011 slightly increased from $28 \%$ to $31.2 \%$, although it should be highlighted that at the beginning of the $21^{\text {st }}$ century, during the period of highest unemployment, the employment indicator was very low (in 2004 it was only 22\%).

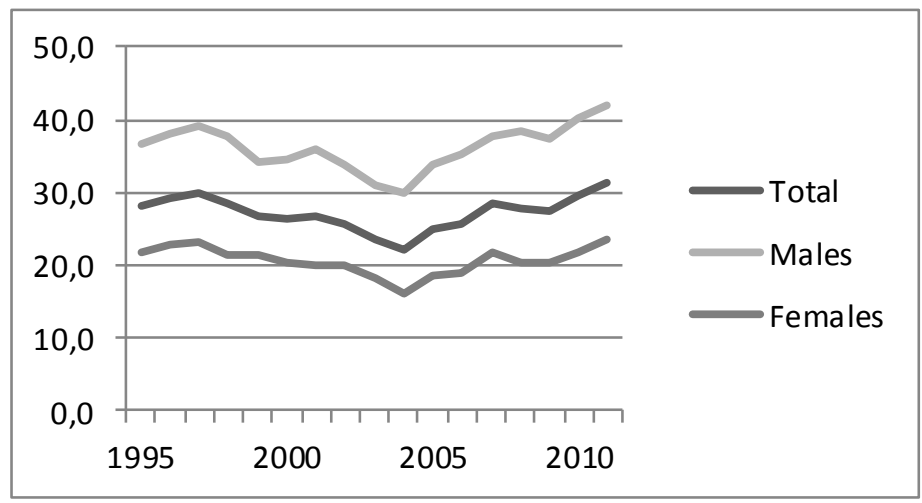

Figure 9 Employment rate for people aged 50+, 1995-2011

Source: Statistics Poland,

http://www.stat.gov.pl/bdl/app/dane_podgrup.display?p_id=6469\&p_token=0.6422432183680485\#

More specifically, the employment rate of people aged 55-65 in 2010 was 32.9\%, which is even lower than in the mid-1990s, when it was $34.4 \%$. These data point to the possibility of the rising level of professional activity of more senior people. Yet, realistically speaking, actions that aim to increase levels of professional activity should be addressed to people already at the age of $45+$. Furthermore, the Łódzkie region is among the very few regions where special attempts to increase the professional activity of people at the age of $45+$ have been made; these attempts go beyond general obligatory activation practices as specified in the Act on Employment Promotion and Labour Market Institutions. The actions were focused on improving the information available on labour markets, and their most important element was a description of the situation of people in the so-called immobile productive age (45+) and identification of 
criteria according to which employers evaluate employees and job candidates. Unfortunately, for the time being, the actions taken include in-depth analytical and diagnostic surveys rather than focused and comprehensive programmes ${ }^{19}$.

Silver economy. There is no data to describe the extent and importance of the silver economy in the region. The data on labour markets presented above are indirect testimony to the growing importance of older workers. It can be presumed that demand for services aimed at these workers is growing. Increasing numbers of pensioners, whose incomes are relatively stable should be treated as a potential resource and thus increase the importance of the elderly as consumers.

White economy. The region also has a well-developed healthcare network. This mostly concerns the city of Łódź, whose network of hospitals and health centres was created in the 1970s and 1980s when the number of residents was higher than it is nowadays by approximately $15 \%$. As has been mentioned above, despite having such a healthcare network, as well as a large number of physicians and hospital places, Łódź shows low objective indirect health condition indices (life expectancy). Access to this type of service is territorially diverse, but is best in the city of Łódź. Łódź contains one of the National Institutes of Public Health, which focuses on pregnant women, mothers and infants. This is reflected in the statistics, since mortality in the first years of life here is lower than the average.

The state of the healthcare sector depends on the regional and local authorities to a very limited extent, since it is the National Health Fund, controlled by state-level authorities, that contract and pay for medical services. Local authorities have, however, founded some institutions offering healthcare services (particularly hospitals) and they are responsible for preventive medicine. In this case, one cannot help but notice that the programmes implemented in the Łódzkie region are orientated towards children and, with regard to the adults, towards screening tests focused on certain select diseases (in some of these programmes, there are also target groups defined on an age basis). However, there are no programmes directed at elderly people. The New Regional Plan to combat depopulation, prepared in December 2012, outlines incentives designed to create regional actions in the field of health promotion aimed at the elderly. Unfortunately, regional authorities have, according to Polish law, very limited opportunities to finance such actions.

Due to today's level of development, the white economy should be treated as a potentially important opportunity for the region. This statement is related not only to medical infrastructure, but also to quasi-medical or "aesthetic" tourism (refer Box 2 on the geothermal waters in Uniejów), which is treated as a very important element in local development. The relatively low level of remuneration is one reason why the most successful enterprises in the white economy field have to focus on external clients, from richer regions, especially from Masovia. Today in Łódź for many medical establishments, particularly those specialising in aesthetic medicine or dentistry, the best clients are those from Warsaw or those living abroad.

\footnotetext{
${ }^{19}$ Urbaniak B., Wiktorowicz J. (eds.), 2011, Raport z analizy programów skierowanych do osób 50+ zrealizowanych w Polsce w latach 2004-2009, Wyd. Biblioteka, Łódź
} 


\section{CHAPTER 4: SKILLS AND TRAINING ECOSYSTEMS}

The region has considerable educational potential, however, due to the proximity of Warsaw, the significance of the Łódzkie region as an academic centre is lower than should be expected. In 2010, 124000 people studied at higher education institutions in the region (by contrast, in 2000 there were 101000 students), of which 56.2\% were part-time students and 39.3\% were students at private universities. It is a disadvantageous situation, since the number of part-time students, whose level of education is generally lower than that of full-time students, was much higher than the national average rate of $45.7 \%$. Furthermore, the percentage of students attending private universities was higher than the average (31.5\% in Poland), and educational institutions of this type generally offer a lower level of education than state universities, which have a more extensive education and research base (libraries, laboratories, workshops, experienced staff, venues, and international collaboration). However, the rise in the enrolment ratio, which in the case of the 19-24 age group increased from $48.5 \%$ to $54.5 \%$ between 2002 and 2010 , should be perceived as a positive phenomenon that indicates a growth in the quality of human resources in the region. What seems less positive is the fact that this ratio has been decreasing since 2008, which is indicative of the decline in Łódź's attractiveness as an academic centre ${ }^{20}$. The most important reasons are: a weak labour market (the graduates cannot find positions adequate to their majors and there is a lack of opportunities to combine education and work); and lack of co-operation between universities and employers. These challenges could best be met by development of practical vocational education via co-operation between employers and academia, but at the same time, some vocational counselling in lower secondary school is needed to counteract bad professional choices made by students. In general, there is no problem finding jobs for graduates in the technical, medicine, and natural sciences areas, but the majority of the secondary school students prefer to study the social sciences.

The vocational education sector is represented by 104 schools located throughout the region. Following the school reforms in 1999, the number of students at vocational schools declined, and some had to be closed down (technical secondary schools were particularly affected). However, the economic revival that took place between 2005 and 2008, when the lack of persons qualified to perform specific jobs was recognised in the labour market, contributed to student candidates and the authorities becoming more interested in this form of education. Nevertheless, job placements and practices still remain a weakness of the vocational education sphere in Łódzkie and, according to entrepreneurs, many schools have not adapted their curricula to entrepreneurs' needs ${ }^{21}$. That is why, in the past few years, the regional authorities have implemented some measures designed to adapt the school curricula to the labour market needs, intensify contacts between schools and entrepreneurs, and provide school laboratories and workshops with modern equipment - see Box 3.

\footnotetext{
20 Główny Urząd Statystyczny, Szkoty wyższe $i$ ich finanse $w 2010 \quad r$., Warszawa 2011, http://www.stat.gov.pl/gus/5840_657_PLK_HTML.htm

${ }_{21}$ Piwowarski R., Uwarunkowania szkolnictwa zawodowego w województwie łódzkim, Wyd. Księży Młyn, Łódź, 2009
} 


\section{Box 3 Measure aimed at vocational education}

The Marshall's Office of the Lodzkie region in the last few years has tried to ameliorate the quality of vocational education by closely co-operating with potential employers of alumni. The co-operation started in 2008, when the first agreement was made with Haering Polska. One of the vocational schools (Publiczna Policealna Szkoła Nowoczesnych Technologii dla Dorosłych w Łodzi - Public Post-secondary school of High-Technology for adults in Łódź) adjusted its curricula and enabled its students to combine education ( 2 days per week) with practice ( 3 days per week within the company).

In 2010, two new agreements were signed, with Ceramika Paradyż and with Paradyż. As a result, special curricula were created to instruct specialists in ceramics.

Source: Dziugieł C. (ed.), Szkolnictwo zawodowe w województwie łódzkim - Analiza desk research, Warszawa 2012, http://szkolnictwo-zawodowe-lodzkie.pl/images/analiza_desk_research.pdf

The capital city of the region has a major potential for higher education facilities (out of 32 higher education facilities in the Region, 27 are located in Łódź, 6 of these being public). Łódź is a leading research centre in Poland, which is also acknowledged abroad, in the realms of chemistry, physics and polymer technology, as well as their application for the production of synthetic materials and fibres ${ }^{22}$.

In terms of higher education, the region is dominated by the three largest state institutions of higher education: the University of Łódź - 43000 students; Łódź University of Technology - 14900 students; and the Medical University of Łódź - 8500 students. Generally, in the last few years, universities have been extending their didactic offerings and, as part of the government's programme of supporting innovative specialisations (science, natural science, and engineering science), new specialisations are being opened up and the students who have chosen the most demanding and time-consuming specialisations receive scholarships for an amount of approximately $40 \%$ of an average salary. The strategy for the Łódzkie region's development focuses its attention on the growth of innovative and creative sectors within the economy. Thus, in upcoming years, the demand for graduates of the afore-mentioned specialisations may increase, and the same situation applies to design specialisations and those related to new materials. This is because, as part of its strategy of development, Łódź aspires to be the fashion and design centre of Poland as well as of Central and Eastern Europe ${ }^{23}$.

In the case of adult education, the region currently lacks comprehensive solutions, which is the result of the national solutions' weakness. The only group whose needs are considered are the unemployed, although in recent years, after accession to the EU in 2004, the Labour Offices have had an opportunity to co-finance training and courses for employed people over the age of $45+$. The weaknesses of institutional forms of adult education have been partly compensated by Universities of the Third Age (educational entities aimed at retired people), whose number has increased in recent years. Usually founded by local associations, the Universities of the Third Age (UTAs) focus on people who have permanently left the labour market, therefore, these universities can be seen as a tool for motivating retirees. Currently, they are present in all but two poviats, while in Łódź, there are six such universities. Every such university offers

22 Rogut A., Piasecki B., Regionalna strategia innowacji dla województwa łódzkiego, Łódź 2008, www.pi.gov.pl/PARPFiles/file/lodzkie_RSI.pdf

${ }^{23}$ Strategia rozwoju miasta Łódź 2020+, Łódź 2012,

www.rzecznik.dlalodzi.info/pliki/.../strategia_rozwoju_miasta_lodz.pdf 
information technology (IT) training, and also often offer language courses, which help prevent the social exclusion of the elderly. The UTAs are a very important initiative, but of course they cover only a small part of the overall elderly population. There are a lack of initiatives focused on populations living in smaller towns and in villages, but this could be at least partially relieved by special programmes issued through the regional television stations, but because of the need for the support of the television stations, the activities need to be accepted at the national level.

In the Łódzkie region, continuing education is delivered by 48 entities accredited by the Łódzkie Board of Education ${ }^{24}$. Half of these entities are located in Łódź, and the education they offer is broader and more specialised. As a consequence, access to courses and training to a large extent depend on the place of residence. There is no regional data concerning the frequency of using continuing education facilities, however, it is feasible to anticipate that there are similarities to the national data, which indicates that continuing education is mainly undertaken by relatively young and well educated people living in large urban centres ${ }^{25}$.

From the perspective of the labour market, it is important that the education level in the Łódzkie region is improving, but the fact that this improvement also concerns education profiles is significant as well. A survey undertaken in 2009 demonstrated that for respondents aged between 16 and 65 years, the following groups dominated: persons holding basic vocational education (21.3\%); and secondary general education (20.1\%); and under the first category, workers involved in the production of textiles and clothing, as well as machinery and equipment mechanics were the largest group. Of the group holding higher education degrees (bachelor degrees), which represented $4.7 \%$ of respondents, those with an education in economics and management dominated (21\%), followed by graduates of engineering and technical studies (18.5\%). In the group of respondents holding masters degrees (13.2\%), the following graduates dominated: economics and management sciences (18.5\%); social and similar sciences (12\%); engineering and technical sciences (11.6\%); and pedagogics (8.9\%). In general, graduates of economics, management and technical sciences were predominately male, while social sciences and pedagogics represented the most selected degrees among females ${ }^{26}$.

The above-listed educational profiles demonstrate that they have poorly addressed the deficit and surplus jobs within the territory of the Łódzkie region. In accordance with the information of the Regional Labour Office, the following professions were in deficit, i.e. there were more job advertisements submitted to the Office than candidates searching for them: maintenance workers; office technicians; stock-takers; cutters - splitters; graders (sorters); and truck drivers. At the same time, the following jobs were characterised by the lowest chance of finding relevant employment: sales assistant; economic technician; technician/mechanic; locksmith; seamstress; tailor; car mechanic; as well as higher school graduates specialising in economics or pedagogics ${ }^{27}$. The regional authorities need to provide vocational counselling at a very early stage in the educational career in order to inform them about the opportunities in the labour market. At the same time, there is a need to develop vocational education, which is less popular in the region than at the national level ${ }^{28}$.

\footnotetext{
${ }^{24}$ http://www.kuratorium.lodz.pl/page/index.php?str=396

${ }^{25}$ http://www.kuratorium.lodz.pl/page/index.php?str=396

${ }^{26}$ Rokicka E., Przybylski B. K., Wykształcenie i dodatkowe umiejętności jako komponenty kapitału ludzkiego, [in:] P. Starosta (ed.), Zróżnicowanie zasobów kapitału ludzkiego i społecznego $w$ regionie lódzkim, Wydawnictwo Uniwersytetu Łódzkiego, Łódź 2012

${ }^{27}$ Rogut A., Niedopasowanie rynku pracy w województwie łódzkim w zakresie zawodów, [in:] E. Kwiatkowski (ed.), Popytowe i podażowe aspekty kapitału ludzkiego w regionie łódzkim, Wyd. Uniwersytetu Łódzkiego, Łódź 2012

28 Dziugieł C. (ed.), Szkolnictwo zawodowe $w$ województwie łódzkim - Analiza desk research, Warszawa 2012, http://szkolnictwo-zawodowe-lodzkie.pl/images/analiza_desk_research.pdf
} 


\section{CHAPTER 5: HEALTH SERVICES FOR SOCIAL TRANSFORMATION AND INCLUSION}

Between 2001 and 2011, in the Łódzkie region, the percentage of people whose income did not exceed the statutory income level fell from $14 \%$ to $5 \%{ }^{29}$. The statutory income level is determined by the Ministry of Labour and Social Policy, and from 2006 until 2012 was equal to 477 PLN per month for single-person households, and 351 PLN per capita per month for larger households. However, in comparison to the other regions, the dynamics of this decline was lower, and as a result, the region's ranking still fell - in 2001, only the Śląskie Region was better placed, while in 2011, four regions were in a better situation ${ }^{30}$. This situation was partly related to the above-mentioned lower dynamic changes in GDP and remuneration level growth within the Łódzkie region.

Within the past few years, a decline in the number of clients using social assistance has also been recorded. In 2002, out of 10000 citizens, 605 people needed such assistance. An increase was recorded in the subsequent years, up to 735 in 2006, but this was followed by a dynamic decline in the number of beneficiaries down to 546 in 2010.

Clients of social assistance mainly represent persons who require the support of the social assistance institution on a regular basis. Of the single parent families and families with several children using this type of assistance who were surveyed by the Regional Social Policy Centre in Łódź, two-thirds use social assistance systematically ${ }^{31}$. The concentration of the poorest people in poverty-stricken pockets is becoming increasingly distinct in the cities of the Łódzkie region, and the entire territory of Łódzkie is characterised by the phenomenon of inherited social assistance beneficiary status. The problem is very serious, because beneficiaries of a second or third supported generation are extremely difficult to integrate back into the preferred life-course of education, work, and retirement. To interrupt the ongoing transmission of this social status, which is of most concern at what is called the NEET stage ("not in education, employment, or training"), special attention should be paid at the early education level, in order to start socialisation processes as early as possible.

In 2011, the main reasons people sought social assistance were poverty, unemployment, longterm illness and disability. The majority of the social assistance institution's clients are assisted through direct financial support. For people with special needs due to age, disability, or temporary illness, some nursing and care services are offered. In 2010, 7921 clients were supported by social assistance.

The social assistance sector is important for the economy of region in its own right, with 9386 full-time employees (1 291 of whom were social workers) employed in the sector in $2010^{32}$. The Regional

\footnotetext{
${ }^{29}$ To a great extent, this significant improvement resulted from the fact that the statutory income threshold has not been re-evaluated in the course of the past 5 years.

${ }^{30}$ At the same time, the data for 2011 indicates that in cases of extreme poverty, i.e. an income level that threatens biological existence, six regions were in a better situation. See GUS, Ubóstwo w Polsce w 2011 r., Warsaw 2012

${ }^{31}$ Warunki życia rodzin wielodzietnych $i$ niepetnych - klientów instytucji pomocy społecznej w województwie tódzkim available at http://www.rcpslodz.pl/Opracowania_i_badania/69/1/

32 Regionalne Centrum Polityki Społęcznej w Łodzi, Ocena zasobów pomocy społecznej w 2012, Łódź, 2011, http://www.rcpslodz.pl/Bilans_potrzeb/96/1/
} 
Centre for Social Policy estimated that 959.1 million PLN would be needed for social assistance services in 2012, while in 2011 it was 856.3 million PLN.

The poor are - in the Polish context - predominantly families with children. Pensioners are in a relatively good situation, due to living in small households where almost every inhabitant has their own income. In 2011, within the region there were: 639500 inhabitants receiving social welfare incomes; 378 200obtaining retirement benefits from the extra-agricultural system; 111500 pensioners receiving benefits from the agricultural system; 67 900- living on disability pensions; and 81 900- receiving family pensions $^{33}$. These people's incomes were significantly below the average gross wage, with typical retirement pay being equal to $55.5 \%$ of the average, mean disability pensions $38.3 \%$ of the average, and retirement pay from the agricultural social security system equivalent to only $32.6 \%$ of the average gross wage.

A very important element of social inclusion is health status. The overall health condition of the Łódzkie population has deteriorated, as noted in the section concerning the indirect health indicator measured as lifetime duration. Surveys concerning self-assessment of health also indicate a lower level of satisfaction in terms of the respondent's health in relation to the national results, as outlined in Table 2.

Table 2 Self-assessment of health (as a percentage of adults who have declared their specific health condition) in Poland and the Lódzkie Region between 1996 and 2009

\begin{tabular}{|c|c|c|c|c|c|c|c|}
\hline \multirow{2}{*}{ 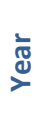 } & \multirow[t]{2}{*}{ Area } & \multicolumn{3}{|c|}{ Males } & \multicolumn{3}{|c|}{ Females } \\
\hline & & $\begin{array}{l}\text { Very good } \\
\text { and good }\end{array}$ & Moderate & Bad and very bad & $\begin{array}{l}\text { Very good } \\
\text { and good }\end{array}$ & Moderate & $\begin{array}{l}\text { Bad and } \\
\text { very bad }\end{array}$ \\
\hline \multirow{2}{*}{ ஓ̆ } & Poland & 58.5 & 26.5 & 14.6 & 51.0 & 30.2 & 18.5 \\
\hline & Łódzkie & 55.4 & 28.8 & 15.3 & 46.2 & 32.8 & 20.5 \\
\hline \multirow{2}{*}{ ষ্ণ } & Poland & 64.5 & 24.0 & 10.8 & 58.3 & 28.2 & 13.2 \\
\hline & Łódzkie & 58.8 & 30.5 & 10.2 & 27.6 & 33.3 & 14.2 \\
\hline \multirow{2}{*}{ 옹 } & Poland & 69.1 & 21.5 & 9.2 & 66.9 & 23.9 & 9.1 \\
\hline & Łódzkie & 62.7 & 25.0 & 12.2 & 59.1 & 26.8 & 14.0 \\
\hline
\end{tabular}

Source: Rynek pracy w województwie łódzkim. Specyfika i uwarunkowania (Labour market in Łódzkie region. Specificity and determinants), Łódź, 2006, www.old.asm-poland.com.pl/diagnozazawodow/publikacja.pdf, Analiza sytuacji społeczno-gospodarczej województwa łódzkiego (Socio-economic situation of Łódzkie region), Łódź 2010, www.si.lodzkie.pl/wcentrumuwagi/diagnoza wl 2010.pdf; Godlewska-Majkowska H., Zarębski P., Atrakcyjność inwestycyjna regionów 2011. Raport syntetyczny (Investment attractively of regions, 2011. Synthetic report), Warszawa 2011, www.paiz.gov.pl/files/?id plik=16734

Analysing the above data, it is worth stressing that not only do a lower percentage of the respondents assess their health condition as good in comparison to the rest of Poland in general, but also, within the study period, the differences between the Lódzkie region population and other residents of Poland has expanded. It should be noted that the self-assessment results are also confirmed by objective indicators, such as frequency of occurrence of various diseases.

The poorer health situation partly results from a more frequent occurrence of risky behaviours. A survey of the condition of the population's health from 2009 indicated that in the Lódzkie region a slightly higher percentage than the national average declared consumption of alcohol (75.8\% vs. $74.4 \%)$, and very frequent consumption (e.g. at least four times a week, $4.9 \%$ vs. $4 \%$ ). Specific concerns result from the fact

\footnotetext{
${ }^{33}$ GUS, Rocznik Statystyczny województw 2012, Warszawa 2012, http://stat.gov.pl/cps/rde/xbcr/gus/rs_rocznik_stat_wojew_2012.pdf
} 
that young people (aged 15 to 29 years) in the region declared a significantly higher frequency $-75.6 \%$ admitted to alcohol consumption, while the average for Poland was $71.5 \%$, and $4.3 \%$ declared that they consumed alcohol at least four times a week as compared to 3\% for the Polish average. Regarding tobacco smoking, the situation in Lódzkie is slightly better than in the rest of Poland in general, with $27.8 \%$ of Łódzkie adults smoking tobacco, and $22.7 \%$ smoked every day while the average for Poland was $29.2 \%$ and $23.8 \%$ respectively. The relevant data for Łódzkie's youth was also slightly better than for the rest of Poland in general ${ }^{34}$.

The poor health condition of the regional population may be the result of various underlying causes, such as stress. In 2009, as many as $6.3 \%$ of the population aged between 16 and 65 years declared that they are constantly affected by stress, and a further $31.8 \%$ declared that they experienced a high frequency of such a state. It is not possible to compare these figures directly with Poland as a whole, however, these values appear to be high ${ }^{35}$.

Between 2000 and 2010, the number of hospital patients in the region increased from 468700 to 643 100. Detailed analyses indicate that this increase mainly resulted from a growing number of hospital patients aged 60+, and, to a smaller extent, patients aged between 20 and 59 years, thus it is primarily a consequence of the ageing of the regional population. This is reflected in an analysis of hospital stays in terms of hospital wards - the number of oncology ward patients has trebled in the above reference period, and doubled in the case of cardiology wards. Although in the period 2000-2010, the number of beds remained practically unchanged (declined by $0.5 \%$ ), this was more due to reductions in the average duration of patients' stays in hospitals from 9.2 days down to 5.4 days, and the hospital bed occupancy rate even fell (from 274 and 256 days of occupancy within a year).

In recent years, due to public support from the European Social Fund (ESF), a substantially increased number of non-government organizations (NGOs) have focused on pre-primary education. Unfortunately, only $72.2 \%$ of children aged 3-6 have access to pre-primary establishments $(83.5 \%$ of those living in urban area, and $55.1 \%$ from rural areas), and an even smaller proportion were able to attend kindergartens (53.8\% of the 3-6 age group, with $73.2 \%$ having access in urban areas, and $24.6 \%$ of those in rural areas). Particularly in rural areas, grandparents, primarily grandmothers, substitute for the services that are lacking for families with young children. This is therefore still the dominant form of intergenerational support, although some new initiatives are emerging (refer Box 6 in Chapter 7). However, discussion about the intergenerational solidarity at the regional level is focused basically on initiatives aimed at education options for the elderly (such as the Universities of the Third Age), and at leisure activities for the elderly.

\footnotetext{
${ }^{34}$ Główny Urząd Statystyczny, Stan zdrowia ludności Polski w 2009 r., Warsaw 2011

${ }^{35}$ Przybylski B. K., Zdrowie jako komponent kapitału ludzkiego, [in:] P. Starosta (ed.), Zróżnicowanie zasobów kapitału ludzkiego i społecznego w regionie łódzkim, Wydawnictwo Uniwersytetu Łódzkiego, Łódź 2012
} 


\section{CHAPTER 6: GREEN REGIONAL/INDUSTRIAL ATTRACTIVENESS}

Geographical and ecological diversity, species-rich plant communities, large populations of wild animals, rare bird species and picturesquely located water basins can provide a sound basis for tourism development. Apart from flat lowlands, which are characteristic in its northern part, at the borders of the Łódź Hills, there are areas of significant relative altitude differences and steep slopes. In the southern part of the region, there are upland areas, with chains of slopes in excess of 300 metres above sea level. Significant diversity in land contours are also to be found in the vicinity of the river valleys, especially the upper sections of the Warta and the Pilica rivers. In the Łódzkie region, there are seven natural landscape parks, 88 nature reserves, 20 nature and landscape complexes, 800 ecological areas (totalling $1380 \mathrm{ha}$ ), a few historical sites and over 3.5 thousand natural monuments. Within the territory of the Łódzkie region, there are nearly 373000 hectares of forests. Among the natural jewels in the region, a few deserve individual mention: Blue Springs Nature Reserve in Tomaszów Mazowiecki; European Bison Breeding Centre in Smardzewice; Arboretum and Rock Garden in Rogów; Spalsko-Rogowski Forest Complex; Korzeń Fen; and a breeding ground for birds in the area of the Jeziorsko Reservoir ${ }^{36}$.

The region was not considered attractive to tourists until recently and therefore has relatively poorly developed tourist facilities in comparison to other regions. However, in the last five years, the use of geothermal springs has developed quickly, for purposes of both heating and, more importantly, for therapy and leisure. The leading area for geothermal springs usage is Uniejów, which is quickly building up its reputation as a health resort. In addition, Poddębice has recently started following this example. Both towns are taking advantage of the closeness of the A1 and A2 motorways in their development. As a result, the regional authorities have started to promote the environmental assets in order to further encourage tourism, and the therapy and leisure sector. For example, at the end of 2012, a special series of maps was distributed across Poland, to encourage tourists to visit the region. However, more effort could be put into encouraging visitors, aimed particularly at clients from Warsaw, the closest major city, which has good transportation systems to the area, and relatively rich consumers.

At the same time, Łódź is beginning to make better use of its large post-industrial complexes, with mini-towns (manufacturing, residential and service buildings) being partially redeveloped. Such activities resulted in the successful creation of Manufaktura, a commercial and services centre, while works to develop an arts and services district are currently being undertaken in Księży Młyn, one of the most interesting monuments of post-industrial architecture.

The region's advantages, on which the present regional strategy is based, are:

- Excellent location regarding transport: there is a new motorway junction planned in the region (near Stryków), as a result of which, the region will be the best located region for investments directed at the Polish market.

- Access to vast workforce resources - not only cheaper labourers with lower-level qualifications, but also highly qualified employees - due to numerous higher education facilities and vocational schools.

\footnotetext{
${ }^{36}$ http://www.lodz.uw.gov.pl/page/26,turystyka-i-rekreacja.html
} 
- The vast scientific and research potential of the higher education facilities and scientific centres in Łódź.

- Considerable brown coal resources, thanks to which, the region has a surplus of cheap electrical energy.

- Abundant resources of thermal waters, which form the basis for renewable energy development and the health-resort role of the region.

- Attractive investment offers for investors in special economic sub-zones.

Key sectors for the region in the strategy of regional development are mainly: power engineering; logistics; the textile industry; agriculture and food; construction; chemicals; and biotechnology.

Unfortunately, the research conducted by the Institute for Market Economics shows that the investment attractiveness of the Łódzkie region has been decreasing for the past few years. For example, in 2009, the region's attractiveness was slightly above average, while in 2011, it was slightly below average $^{37}$. The weakening position of the region results from a negative evaluation of the local sales market (market size and absorption rate resulting from the amount of income) and public safety level (crime frequency) - in both areas, the region rated 11th out of 16 regions, and poor transportation accessibility, in which it ranked 9th. The transport situation, however, has improved significantly already in 2012, with the motorways enabling direct access to Warsaw and the seaports, and a new airport terminal in Łódź having opened. The best way to attract investors is to develop the road and motorway system to better enable localisation of the region. The latest successes of Łódź in attracting investors (including HP and Samsung) are assessed as being the result of reorganisation of the Mayor's office, which has been redesigned to be more helpful in providing potential investors with information and at times acting as intermediaries in contact with public offices.

Completely different issues are at the heart of the green economy. In the case of waste management in the region, a diagnosis delivered in 2007 indicated the following issues: ${ }^{38}$

- Apart from landfills, the lack of a sufficient number of installations for the processes of recovering and rendering communal waste harmless, biodegradable waste in particular, and consequently, insufficient quantities of waste undergo biological processes and thermal processing.

- Insufficient progress in selective collection of communal waste, including hazardous waste, entering the communal waste stream.

- Lack of an organised system of collection, recovery and rendering hazardous waste from dispersed sources harmless.

- Depositing excessive quantities of waste in landfills (in 2006, the following quantities of waste were rendered harmless via landfills: $72 \%$ of communal waste; $22 \%$ of hazardous waste; and $29 \%$ of waste other than communal and hazardous).

- Low charges for depositing mixed communal waste.

- Incompliance by a significant number of landfills with the best available techniques (BAT) used for waste other than hazardous and neutral, where communal waste is deposited.

- Low efficiency rates of municipalities in activities related to establishing joint, over-arching organisational entities that could deliver complex programmes of communal waste management.

\footnotetext{
37 Instytut Badań nad Gospodarką Rynkową, Atrakcyjność inwestycyjna województw i podregionów Polski 2011, avaiable at http://ibngr.pl/index.php/pl/lewe_menu/atrakcyjnosc_inwest_wojewodztw

${ }^{38}$ Lódzkie Region Board, Plan for Waste Management in Łódzkie Region 2011 (this also considers the period between 2012-2015), Łódź 2007,

http://www.biplodzkie.lodzkie.pl/export/system/galleries/externallinks/srodowisko-programy/pgowl-2011.html
} 
- Difficult economic situation of many economic entities, and capital-related barriers with respect to implementation of modern technological solutions that could contribute to minimisation of the quantity of waste produced as well as increasing the extent of its recovery.

- Lack of instruments with which to discipline territorial self-government entities if they do not comply with their statutory obligations.

The green economy could be a potential growth area in the future, but only through European Union priorities and subsidies. The extremely high cost of investments in waste management is completely unaffordable for local authorities without external support. 


\section{CHAPTER 7: REGIONAL/LOCAL INITIATIVES AND POLICY ISSUES}

\subsection{Local initiatives}

The extended infrastructure that exists within the scope of higher education and healthcare facilities may be seen to serve as a basis for the future advancement of developmental strategies for the knowledge-based and "white" economies related to these fields. However, the analysis of strategic documents shows that such an assumption is not entirely true.

In the official documents, the demographic factor is visible only as a variable to which we have to adjust but which cannot be shaped. The Development Strategy for the Łódzkie region for the years 2007-2020 $0^{39}$ generally neglects demographic problems as a whole and rarely mentions actions facilitating adjustment to population changes as operational objectives. The situation will change in the future - in the new strategy of the region, which is now being prepared in the Marshal's Office, the demography is treated as one of the most important problems of the Łódzkie region. This document, the Plan to Combat the Depopulation of the Eódzkie region, 2013-2014 was in the social consultation phase at the end of 2012. ${ }^{40}$ The plan, which is subtitled "Family - children - work", focused on rebuilding human capital and on ameliorating quality of life. The crucial proposed activities could be divided into two groups: the first one consists of activities whose costs could be attainable, primarily via public funds (especially the European Social Fund); the second one is a list of activities that are desirable, but which require changes in law and the budget of the region. ${ }^{41}$

The priority problems that were specified in the still valid Strategy of Social Policy for the Łódzkie region for the years 2007-2020 $0^{42}$ include: poverty; long-term unemployment; the crisis of family; social exclusion; addictions; providing equal opportunities for the disabled as regards social and professional rehabilitation; the ageing of society; and the infrastructure and systems of support.

The above-mentioned issue, which highlights the documented importance of demographic changes, results from the evident focus of strategic documents on "hard" actions associated, above all, with the development of infrastructure, and attracting investments that offer new jobs. Such promotion of traditionally understood investment contributes to a certain level of neglect of other actions, and renders social expenditure of secondary importance. However, some changes are noticeable - during the debate

\footnotetext{
${ }^{39}$ Łódź Region Assembly, The Development Strategy for the Łódź Region for the years 2007-2020 (English version), Łódź 2006,

http://www.lodzkie.pl/wps/wcm/connect/bip/bip/urzadmarszalkowski/programy/strategiawojewodztwalodzkiego/strat egia_rozwoju_wojewodztwa_lodzkiego_na_lata_2007-2020_2.pdf

http://www.lodzkie.pl/wps/wcm/connect/bip/bip/urzadmarszalkowski/programy/strategiawojewodztwalodzkiego/prac e_nad_aktualizacja

${ }^{41}+$ Urząd Marszałkowski w Łodzi, Plan przeciwdziałania depopulacji w województwie łódzkim na lata 2013-2014, Łódź 2012

${ }^{42}$ Łódź Region Assembly, The Strategy of Social Policy for Łódź Region for years 2007-2020, Łódź 2007, dostępna na http://www.rcpslodz.pl/Strategia/19/0/
} 
regarding updates of the regional and Łódź city strategies, many voices were raised, arguing that, instead of focusing on the level of economic development and infrastructure, *residential living standards should be the primary concern. Relevant authorities decided to rework the drafted document, ${ }^{43}$ with one of the factors contributing to this rework being the heated debate that started after the announcement of the most recent population projection by the Central Statistical Office, which predicted that, within twenty-five years, the population would decrease by a quarter. In the city strategy, reversal of adverse demographic trends was assessed as being one of the six most important aims for attainment.

Several strategies have been put in place but these actions are, however, mostly reactive and they do not aim to shape the population processes. One such example is the reaction of the authorities to the decreasing number of children and teenagers of school age. In accordance with a City Council resolution, eight schools in Łódź, and a total of 70 across the region, are to be closed in 2012 alone. The situation has been the same for the last two years (2010-2011), that is, since the start of the economic crisis, the local governments realised that, due to the lower number of children and teenagers, they could reduce the schools network, thus limiting the costs of education (noting that subsidies from the central budget depend on the number of students, as a result of which larger educational institutions. with lower average costs per student, receive more relative financial support). To convince the public of the changes, there is a need for social consultation and transparency - why should that particular school be closed. Information on demographic change at local or sub-local levels should be made accessible to inhabitants and their representatives.

In the case of the health service, local governments attempt to influence only the subordinate health-care institutions, which means mostly hospitals; however, attempts to merge hospitals are made only in Łódź. These endeavours are often economically-motivated and they do not take demographic factors into account. Łódź is an exception - the Śródmieście (downtown) district is replete with health-care institutions established in the interwar period, and three decades after World War Two, while in the last fifty years, the number of residents of the district decreased by $55 \%$, therefore, voices have been raised, arguing that some health-care institutions should be relocated to other districts, thus adjusting to the current distribution of citizens.

The limited attention to demographic factors can be seen in the social assistance directives. For the last two years, the Regional Centre of Social Policy in Lódź (an entity subordinate to the Regional Marshall, and responsible for supervising social assistance institutions) has been organising conferences for seniors' organisations and social workers, which aim to exchange experiences and motivate senior citizens. Unfortunately, the results of these actions are rather poor. This can be observed in Łódź, where the first 'Centre for Active Seniors' was opened in 2011 at the local community centre. The aim of these centres is to stimulate social integration of the elderly through access to cultural, educational and leisure goods and services at discounted prices. However, there is a clear lack of a more comprehensive policy. The actions taken are undoubtedly oriented towards supporting the elderly, but without any attempt to create a policy that is focused on old age as a stage of life; in other words, from the perspective of it being part of the general life-cycle. The sphere of social policy and social assistance is mainly oriented towards material help for people with no income, or those in a difficult situation, leaving the promotion of the active neglected. Some efforts are needed to transform the way of thinking of decision-makers and of people implementing the policy, to focus on using a life-cycle approach; i.e. to disseminate awareness that it can be much easier to achieve some results affecting earlier stages of life.

The lack of integrated actions, or rather, reactions to the current demographic and social changes, are partly compensated for by the activity of third-sector institutions, such as the recent development of the

\footnotetext{
43 City of Łódź, “Integrated Development Strategy for Lodz 2020+”, Łódź 2012, http://www.uml.lodz.pl/miasto/strategia/
} 
Universities of the Third Age, which usually operate as associations, and which frequently receive public support in the form of lending meeting space. Associations, foundations and now also, thanks to the financial resources of the European Social Fund, other entities of social economy, have been trying to function in this field. One factor encouraging such activity is the high level of unemployment among young people, some of whom perceive founding and running such organisations as a means of work (such as social sciences students). By these means, entities oriented towards helping seniors and offering either childcare or elderly care, are established. What these entities all have in common is that they take action in a field for which they can rely on at least partial financial support from the public budget, which means that they are largely based on EU priorities. However, the situation is changing, for example, in 2011 the City Council appointed a special Seniors Council, which commenced in the summer of 2012.

The market sector reacts less dynamically to demographic changes. This is a result of the level of wealth in Polish society, since, as has been mentioned, the inhabitants of the Łódzkie region receive belowaverage incomes. Thus, the "silver economy" has not yet had a chance to develop in the region, although in Łódź, one may observe first market initiatives oriented towards the well-educated and more affluent seniors from the urban areas. Public policy should therefore promote elderly community groups as a positive example of organisations aimed at raising seniors' quality of life and as an example of noncommercial entities. Entrepreneurship of the elderly should be promoted, especially if the newly established enterprises would be quasi-commercial, i.e. produced utilities would be priced lower than their market equivalents.

Demographic data presented in this paper clearly indicate that from the perspective of both the Łódzkie region and its capital city, which houses $30 \%$ of the region's population, demographic transformations will be of key importance in identifying development-related opportunities. Regional and local authorities are aware of this fact and although it has not yet led to recording clear responses to the occurring demographic changes in the adopted development strategies, increasingly often adaptationoriented measures are implemented. The following text presents two examples of such measures delivered in Łódź. Firstly, in order to attract young people to the city, its authorities started to implement the "Młodzi w Łodzi" (Youth in Łódź) programme - Box 4. At the same time, awareness of the fact that the population ageing process is progressing quickly, as well as an aspiration to improve quality of life for senior citizens, and to provide them with opportunities to spend their time actively, have contributed to development of the "60+ Activation" programme - Box 5. These senior-focused activities are not only developed and promoted by the local authorities. Some senior self-organisational activities are in existence, for example, the ‘Flying Grannies’ (Latające Babcie) - Box 6.

\section{Box 4. Youth in Lódź}

"Youth in Łódź" is a complex programme implemented by the Bureau for Enterprise and Jobs Development of the Łódź City Office, in co-operation with higher schools and leading employers in Łódź. The programme's objective is to encourage young people to link their future with that of the city of Łódź. Increasing the number of people studying relevant courses that are required by employers, is an important element of this programme, which will then translate into having graduates of the required quality, while improving the image of Łódź as a city friendly to vocational development.

Tools to deliver these goals include the following initiatives of the programme: a website with information on work practices and placements; scholarships for top students, funded by employers as programme partners, financing student's accommodation and training via scholarships such as - "Your Career in Your Hands" competition; "I have an Idea for a Business" project; "Practice in Łodź"; a cycle of visits in Łódź companies under the catchphrase: "Meet Łódź Employers"; a merit-based competition titled "FreeDOM (freeHOME) for Student”; and information and publicity campaigns addressed to young people.

"Youth in Łódź" was launched on 18 March 2008. Thanks to the broad involvement of the campaign partners; 
universities (Łódź Technical University, University of Łódź and Medical University), and Łódź employers; the programme undergoes continuous development. Currently, it co-operates with more than 60 companies, where almost 30 take part in those programme initiatives deemed most efficient (by the organisers) i.e. the scholarship scheme and project of paid summer job placements "Practice in Łódź". In the three iterations held so far, employers funded 67 scholarships for the top students of Łódź universities, funded accommodation in student hostels for 9 students, and English language courses for 42 students.

The "I have an Idea for a Business" competition is an initiative which aims to distinguish and support implementation of the best business plans from future and currently operating young entrepreneurs within Łódź. All the participants have an opportunity to take part in free of charge training and individual consultations, with the best projects receiving financial awards, notebook computers, printers, language courses, and free of charge accounting services for their future enterprise.

Source: www. mlodziwlodzi.pl/

\section{Box 5. 60+ Activation programme}

Łódź authorities started to recognise the need to address the social needs of elderly citizens, which they addressed by the launch of the "60+ Activation" programme, which started in 2012. This is designed to become a multi-elemental and phased initiative, to improve the living standard of senior citizens by providing them with options for activities in various fields. Establishing the City Council of Senior Citizens as an opinion-issuing and advisory body to the City Council in 2011 was the first element.

The Centre of Łódź Seniors, and Seniors Activity Centres, located in cultural facilities in each district, started to operate in January 2012. The urban programme assumes activities in the fields of education, dissemination of culture, and health prevention measures addressed towards elderly people. The Centres propose cabaret, choirs, excursions, social dancing, courses in self-defence, photography and English. Typical activities offered by the Centres cover measures focused on the areas of: general advice (health, personal finance management, law and safety); education (computer skills and foreign language courses); physical activities (dancing, fitness, walking) and culture (film shows, artistic workshops).

The next step will include development of district clubs for seniors and centres of activity in the vicinity of beneficiaries' homes, as well as introduction of new improvements that will make senior citizens' lives easier. Enhancement of the offers addressed to elderly people are also planned. In 2012, the city officials plan to provide 125000 PLN for the “60+ Activation” programme.

Measures planned for implementation since July 2012 include introduction of a city card for 60+ citizens, which offers discounts and exemptions for the city's culture, tourism and sports-related activities and, beginning in 2013, development of a special programme that will, among other things, enable senior citizens to change accommodations. In parallel, there will be measures aimed at adapting urban infrastructure to help meet senior citizens' needs, launch a centre for geriatrics (2013) and vocational activation within the labour market of citizens aged $50+$.

Source:http://www.uml.lodz.pl/miasto/aktualnosci/?news=19550; and

http://www.uml.lodz.pl/miasto/aktualnosci/?news=20381

\section{Box 6. Flying Grannies}

This project was implemented in 2008 as an initiative of intergenerational leaders Bogna Stawicka and Magdalena Dunaj, who launched workshops for writing and telling fairy tales, addressed at senior female Łódź residents. Willingness to stimulate creativity, making use of the life wisdom of senior women, was the motivation behind implementation of this project. During the workshops cycle, women learn how to write and tell fairy tales, as well as how to promote the outputs of their work. The focus on fairy tales is based on the fact that they provide an excellent form by which to disseminate knowledge and experience. Urszula Machcińska, a workshop participant, developed the project in consecutive years. Every year, a group of seniors takes part in literature and theatre workshops, as well as training in the field of effective communication and teamwork. Flying Grannies learn how to write empathic and therapeutic stories. Based on their texts, they prepare plays for children, which are then performed in hospitals, after-school facilities and other institutions for children. Stories 
written by the women are also published. In 2012, the Flying Grannies started to work with Łódź Radio, with whom they co-present a fairy tale programme for children.

Source: kobiety.lodz.pl

Two social co-operatives, which operate in Łódź, in a degraded area in the vicinity of Legionów and Gdańska Streets, and which were visited by the OECD delegation in March 2012, have been established with the aid of financial support offered under the European Social Fund.

- The first co-operative is an initiative of five young Łódź citizens, graduates of the humanities and social arts, who could not find work, and started up their own firm called “Zaraz wracam” (I'm just going to come back), which is a coffee-bar club. Members of this co-operative rented a facility from the city of Łódź, in which, apart from the strictly commercial service provision, they organise discussion meetings and concerts of alternative music.

- The second social co-operative - DOM (Home) - is an initiative of graduates of the schools of art, who established a music club. The club is located within the Off Piotrkowska zone. The Orange Property Group (OPG) came up with the idea of the Off Piotrkowska area, and they co-ordinate it. The project's objective is to create an alternative to the consumption-oriented, mass produced fashion, which predominates in our times. Following the crisis-related suspension of business plans to reconstruct a former factory into a modern hotel and office building, instead of paying fines to the city of Łódź for giving up implementation of the investment, which resulted from the contracts of purchase of the land, which was located in a very attractive place, the Orange Property Group decided to help tenants to start up their operations by offering low rent, renovation of the adjacent areas and promoting all the entities under the same logo of Off Piotrkowska. Most of the tenants are young designers and entrepreneurs focused on production of clothing and jewellery in small batches, characterised with unique patterns and a significant contribution of hand-made elements. DOM is a music club oriented on alternative music. It holds concerts every day, and dancing events at the end of the week.

It is worth mentioning that the area of Legionów and Gdańska Streets is located in a district of Łódź that is one of the most degraded and threatened with social problems. Studies delivered by Łódź sociologists from the school of W. Warzywoda-Kruszyńska indicate that several poverty pockets are found in this area, which are characterised by severe problems of unemployment, alcoholism, inability to pay rent, low standard of residential spaces, crime rate and early school leavers ${ }^{44}$. Initiatives to address this area have had limited results.

\subsection{Small scale policy survey}

Local stakeholders participating in a workshop in the region were asked to respond to a short questionnaire regarding two important aspects of adaptation to the needs of senior citizens: place of residence in a broad sense, including public space and social services offered in their local area; as well as conditions of work and employment. A survey delivered during the seminar in Lódź, which was completed in May 2012 by the participants of a seminar focused on social policy in Lódź and the region, in the context of demographic transformations in general, indicates a low grade of adaptation by the local environment to the needs of senior citizens. Similar conclusions have been demonstrated in both the survey Elderly Friendly Places to Live - OECD ELFRI Index, and Older Workers Friendly Places to Work OECD OLWOF Index.

In the first case - if we consider the calculated average scores, which are based on the opinions provided by the respondents, where the value of 1 indicates a low score and 5 high - a clear concentration 
of responses with low values is noticeable. The item Respect and social inclusion (2.15) was the highest ranked, mainly due to the positive scoring for the position of senior citizens in the family (although, in this case, the scores of the individual respondents also indicated a significant differentiation).

Figure 10 illustrates the elements of the ELFRI index

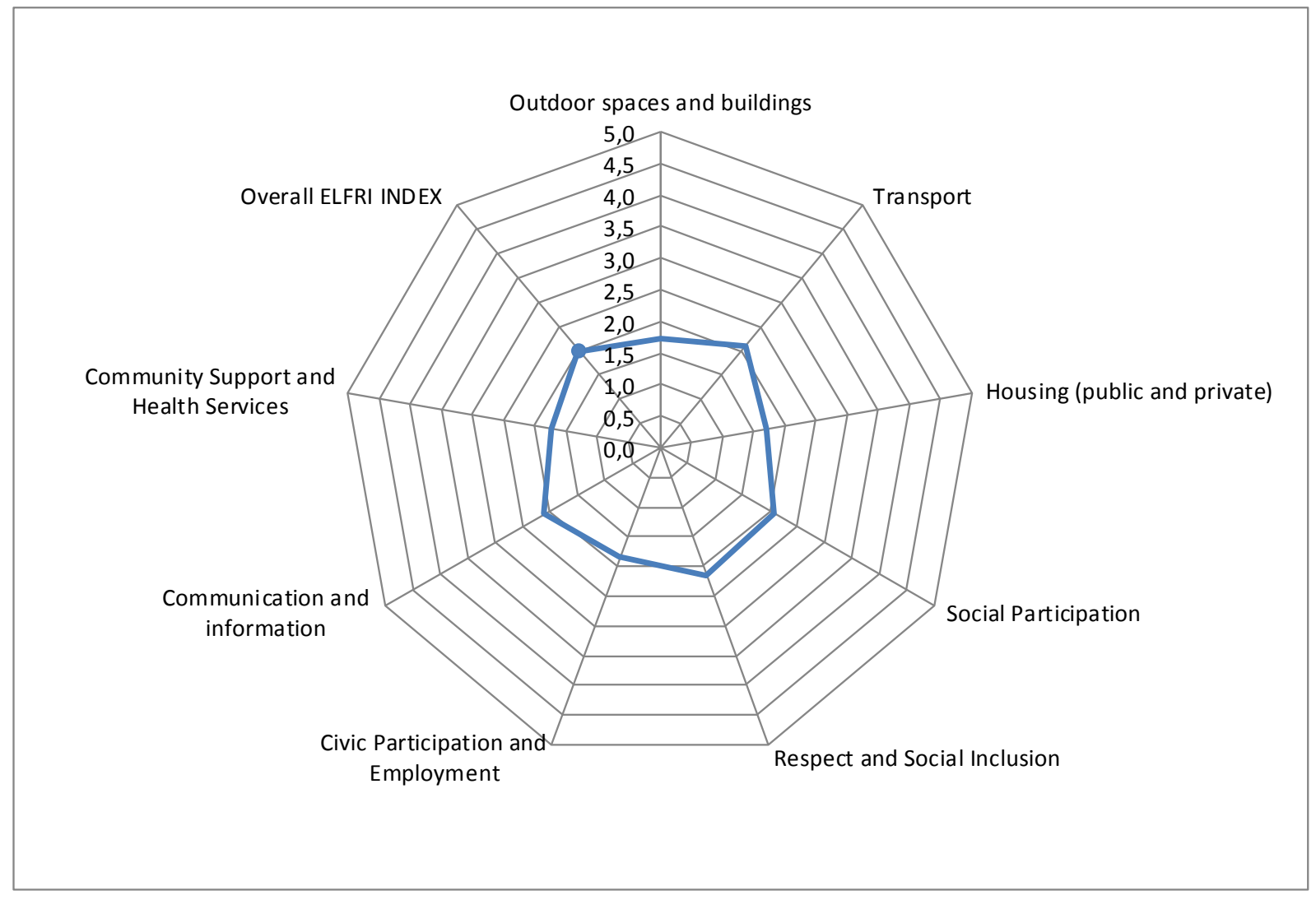

Figure 10 Elements of the ELFRI index scores

Community support and health services (1.73) and Housing (1.77) obtained the lowest scoring, indicating the respondents' lack of confidence in the capacity of the public authorities to provide social services of the appropriate range and quality. Significant conformity of the scoring was of special interest scores of 4 and 5 were usually awarded by only $6-8 \%$ of the respondents, although in the case of Housing, it was represented by only 1\%, Community support and health services - 3\%, and Civic participation and employment $-4 \%$.

The overall ELFRI index for the Łódzkie region is 2 out of 5 (where 1 is poor and 5 is excellent), which makes it below average as an elderly friendly place to live. More specifically, the ELFRI topic index is as follows: outdoor spaces and buildings 1.7; Transport 2.1; Housing 1.7; Social participation 2.1; Respect and social inclusion 2.2; Civic participation and employment 1.9; Communication and information 2.1; and Community support and health services1.7. Generally, according to the index, the Łódzkie region can improve significantly as an elderly friendly place to live. 
Equally low values were obtained in the case of the second study aspect related to the friendliness of the workplace towards senior citizens. The values generally oscillated around 2, however, the analysis of the responses obtained is complicated by a high number of responses ignored by the respondents.

Figure 11 illustrates the elements of the OLWOF index.

In this case, recruitment received the lowest score (1.85), however, it should be considered that the OLWOF is of a different nature than the ELFRI - the respondents sometimes assessed very detailed issues in which they were not directly involved and about which they formed ad hoc opinions (e.g. availability of on-line training, which was reflected by a significant proportion of Łódzkie respondents leaving this question without answer). Thus, in comparison with the ELFRI, which is mainly based on every-day life experience, the OLWOF consists of a projection of the relation of the respondents to the measures of the labour market addressed to senior citizens, rather than the real measures implemented by the labour market institutions. The overall OLWOF index for the Łódzkie region is 2.1 out of 5 (where 1 is poor through to 5 being excellent), which categorises the region as having a poor Older Workers Friendly Places to Work index. More specifically, the OLWOF topic index rates as follows: Recruitment 1.9; Work culture and opportunities 2.1; Training and skills development 2.1; Firm health and benefits 2.3. Significantly, the overall importance of OLWOF for the Łódzkie region is 3.8, which categorises the region as average. More specifically, the importance of OLWOF topics is as follows: Work culture and opportunities 3.8; Training and skills development 3.5; Firm health and benefits 4.2. The slow realisation of the importance to the regional and local economy of older people's work contributions reflects the delayed response in developing strategies to keep older persons in employment and contributing to the regional and local economies. Nevertheless, there is still a significant policy gap between reality and what needs to be done.

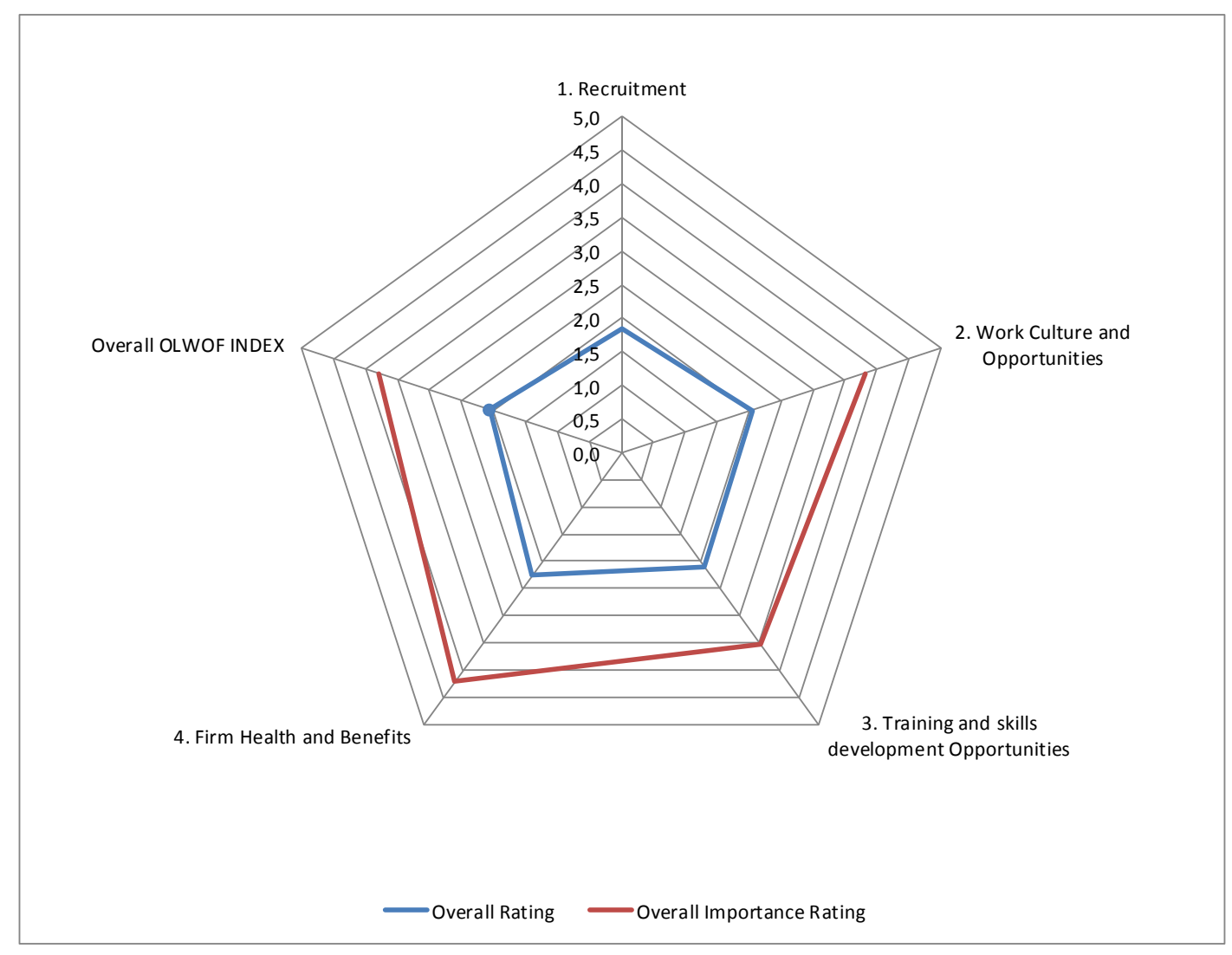

Figure 11 Elements of the OLWOF index scores 
The small-scale survey revealed a number of policy areas that require attention, programmes, initiatives and strategies to be developed, implemented and monitored for the older workforce and the elderly living within the Łódzkie region. The following section provides key findings and recommendations. 


\section{CHAPTER 8: KEY FINDINGS AND RECOMMENDATIONS FOR LÓDZKIE}

In summary, despite the awareness of the upcoming depopulation of the Łódzkie region (predicted through to the year 2035), and the rapid ageing of the population, local authorities, both at the regional and the local level, are taking only reactive actions in this field. They perceive infrastructure projects that aim to attract private investment and create workplaces as the means by which to shape population processes, facilitate taking the most important decisions (migration, marriage, and children) and, consequently, solve the majority of demographic problems. The situation may, however, change very shortly due to a new developmental strategy of the region, which is currently being discussed. The latest population projection, particularly the expected sharp population decline, has influenced the regional authorities to begin to treat demographic changes as extremely important threats to the future of the region.

Meanwhile, there is currently no overall policy addressing demographic transformations. Underdevelopment of family policy is mainly due to the unsatisfactory activities of the central authorities, which have not elaborated consistent and efficient pro-natalistic and pro-marriage solutions. Transfer of family policy measures to the regional government, which has been observed within recent years, is usually not accompanied by adequate funding.

Moreover, there is no policy addressing transformations concerning age structure, ageing of the population in particular. An adequate offer of medical services for senior citizens, primarily specialised services such as geriatric consultation, physiotherapy and medical check-ups, is also missing. Studies undertaken demonstrate that health education and promotion also remain at an insufficient level.

There is poor co-operation among local entities rendering public services to citizens, which has been revealed both thanks to the studies into the requirements of children in unfavourable situations (poor and disabled children, as well as children with special educational needs), and studies of the needs of citizens aged $50+{ }^{45}$.

The largest deficits in the measures delivered by the local authorities occur in urban-rural municipalities, where the traditional power of family and neighbourhood links are slowly disappearing, and, due to high unemployment levels and low salary levels, it is not possible to refer to the free market ${ }^{46}$.

Measures taken by the local authorities are often short-term (typically "putting out fires") and concentrate on what are considered to be tangible results (infrastructure development in particular), and consequently, the anticipated demographic challenges are of relatively little significance. Certain changes are enforced by the EU programmes - authorities which take part in transferring EU funding to final beneficiaries are required to observe the guidelines of the European Commission. In late 2011 and early 2012, there was increased interest in the issue of active ageing, as a result of the European Year of Active Ageing and Solidarity between Generations.

\footnotetext{
${ }^{45}$ Results of the WZLOT Project are available at http://www.wzlot.uni.lodz.pl/; Diagnoza sytuacji osób starszych w województwie tódzkim, http://www.rcpslodz.pl/Opracowania_i_badania/69/1/

${ }^{46}$ Diagnoza sytuacji osób starszych $w$ województwie łódzkim, http://www.rcpslodz.pl/Opracowania_i_badania/69/1/
} 
In terms of demographic issues, key areas of future activities to be taken by the regional authorities include:

- Enhancing the living standard of the inhabitants in order to improve residential attractiveness. This type of measure should be focused on providing stable and reasonably well-paid jobs on the one hand, and good living environments and friendly residential spaces on the other.

- Making the decision to have children easier - by making it easier to harmonise professional career and family life, as well as by introducing economic instruments designed to help offset the costs of raising children (e.g. the "Big Family Chart", which is implemented by several local governments, to provide families with at least three children with access to services offered by enterprises owned by these governments at reduced prices).

- Increasing the willingness and options for senior citizens to maintain their activity in various fields - in several years' time, the regional labour market will face problems with insufficient numbers of staff in some sectors, thus, the easiest solution to this problem will include the extended vocational activity of citizens at retirement age.

- Improving the human capital level by providing access to education and health care adapted to the specific stage of life.

- Strengthening the role of the Łódź metropolis as a regional centre of innovative technologies and economic growth services, as well as a driving force for development of the whole region.

In light of the results of the current review of the situation in the Lódzkie region, several recommendations for further development are proposed:

- Diagnosis of the needs resulting from demographic transformations at the local level (municipalities and counties, depending on their tasks assigned by virtue of law) should be undertaken, in order to ensure that, on the one hand, social services can meet the demands that will be placed on them, and on the other hand, to prepare well in advance for the inevitable changes that will occur.

- Greater promotion of the need for increased awareness by territorial governments of the demographic forecasts made by Statistics Poland for their regions and counties, as these will help predict the futures of their localities.

- Creation of a special institution (eg. a 'demographic observatory'), answerable to the regional authorities, which will focus on diagnosing, projecting and disseminating their research results to regional and local authorities, will help to realise the first two recommendations.

- Provision of conditions favourable for procreation, which includes ensuring stable professional careers for potential parents, and facilitating vocational activity for mothers by providing them with good quality and affordable childcare, is of vital importance to the demographic future of the region.

- Promotion of alternative methods of childcare, such as via certificated, registered and supervised child-carers (the French assistant maternel), who could create mini-creches in their own homes, would help make having children more attractive to working women. As mentioned earlier, relatively high female economic activity in the region is linked to low fertility rates.

- Special attention should be paid to programmes aimed at attracting young people to settle in the regional capital, especially young people currently living in regional areas. Interviews with representatives of younger generations ${ }^{47}$ underlined the importance to them of non-material lures (such as cultural events, regional public transport organisation) and opportunities to gain professional experience.

\footnotetext{
${ }^{47}$ Interviews undertaken in November 2012, as part of research activities in the framework of initiatives aimed at preparing a demographic strategy for the Łódzkie region.
} 
- Concentration of the financial support from the EU to employers should be within a few strategic fields, with higher shares of knowledge saturation - e.g. biotechnologies, creative industries, and the recreation industry.

- Promotion of healthy living is needed, particularly for people in their 20s, 30s and 40s, in order to offset the high death rate and worsening health condition of the Łódzkie citizens.

- Public actions targeted at living an active life are needed for people who have recently retired - fee structures of activities promoting such a lifestyle to senior citizens should be reduced in recognition of their low levels of income.

- Creation of local networks of "surrogate carers", who can temporarily replace family carers of the elderly, would be very beneficial, as they could give them some respite to go on holidays, or provide assistance if they become ill. People early on in their retirement could be a natural reservoir of these "surrogate carers"; many of them are very well prepared to watch over the elderly, due to previous experience caring for their own parents.

- Revitalisation of the core of the region; the capital of the region and its surrounding poviats, is needed to counteract the potential lack of regional economic gravity towards the centre. The idea of a duopolis, with close co-operation occurring between Łódź and Warsaw, accenting each city's specialisation, should be strongly supported.

- Creation of the duopolies of Warsaw and Lódź is possible if funding from different regions is combined. One important element of the revitalisation of Łódź is the combining of the three Łódź universities into a single higher-education institution - the "University of Central Europe".

- Revitalisation of Łódź tenement-houses could be brought about by creation of a mechanism that would enable easier transferral of ownership of communal static property to joint possession (wspólnota mieszkaniowa). 


\section{REFERENCES}

City of Łódź, Integrated Development Strategy for Lodz 2020+ (English version), Łódź 2012, http://www.uml.lodz.pl/miasto/strategia/

Diagnoza sytuacji osób starszych w województwie tódzkim (The elderly in Lodzkie region - social diagnosis), http://www.rcpslodz.pl/Opracowania_i_badania/69/1/

Dorożyński T., Urbaniak W., Rola jednostek samorząu terytorialnego we wspieraniu inwestorów zagranicznych $w$ województwie tódzkim (Role of regional selfgovernment in supporting foreign investors in Lodzkie region), Łódź 2011, www.biz.uni.lodz.pl/?dl id=60

Dziugieł C. (ed.), Szkolnictwo zawodowe w województwie tódzkim - Analiza desk research (Vocational education in Łódzkie region - desk), Warszawa 2012, http://szkolnictwo-zawodowelodzkie.pl/images/analiza desk research.pdf

Główny Urząd Statystyczny, Stan zdrowia ludności Polski w 2009 r. (Health status of the Polish population, 2009), Warsaw 2011, http://www.stat.gov.pl/gus/5840_658_PLK_HTML.htm

Główny Urząd Statystyczny, Szkoły wyższe i ich finanse w 2010 r. (Higher education institutions and their finances in 2010), Warszawa 2011, http://www.stat.gov.pl/gus/5840 657 PLK HTML.htm

Główny Urząd Statystyczny, Ubóstwo w Polsce w 2011 r. (Poverty in Poland in 2010), Warsaw 2012

Godlewska-Majkowska H., Zarębski P., Atrakcyjność inwestycyjna regionów 2011. Raport syntetyczny (Investment attractivity of regions 2011. Synthetic report), Warszawa 2011, www.paiz.gov.pl/files/?id_plik=16734

Instytut Badań nad Gospodarką Rynkową, Atrakcyjność inwestycyjna województw i podregionów Polski 2011 (Investment attractiveness of regions and subregions, 2011), http://ibngr.pl/index.php/pl/lewe_menu/atrakcyjnosc_inwest_wojewodztw

Kaczorowski P., Samozatrudnienie jako forma rozwoju przedsiębiorczości w województwie łódzkim ocena dotychczasowego stanu, bariery i perspektywy (Self-employment as a form of employment in Lodzkie region - today situation, barriers and perspectives), [in:] E. Kwiatkowski (ed.), Popytowe i podażowe aspekty kapitału ludzkiego w regionie łódzkim (Supply and demand and human capital in Lodzkie region), Wyd. Uniwersytetu Lódzkiego, Łódź 2012

Kubiak P., Równość kobiet i mężczyzn na rynku pracy w województwie łódzkim i jego powiatach (Gender equity on the labour market of the Lodzkie region and its poviats), [in:] E. Kwiatkowski (ed.), Popytowe i podażowe aspekty kapitału ludzkiego w regionie tódzkim (Supply and demand and human capital in Lodzkie region), Wyd. Uniwersytetu Łódzkiego, Łódź 2012

Kwiatkowska W., Poziom oraz struktura sektorowa i zawodowa popytu na pracę w województwie łódzkim i jego powiatach w latach 1999-2009 (Level and structure by sector and vocation of demand on labour in Lodzkie region and in its poviats, 1999-2009), [in:] E. Kwiatkowski (ed.), Popytowe i podażowe aspekty kapitału ludzkiego w regionie tódzkim (Supply and demand and human capital in Lodzkie region), Wyd. Uniwersytetu Łódzkiego, Łódź 2012 
Łódzkie Region Board, Plan for Waste Management in Łódzkie Region 2011 (it also considers the period between 2012-2015), Łódź 2007, http://www.biplodzkie.lodzkie.pl/export/system/galleries/externallinks/srodowiskoprogramy/pgowl-2011.html

Łódzkie region Assembly, The Development Strategy for the Lódzkie region for the years 2007-2020 (English version), Łódź 2006 http://www.lodzkie.pl/wps/wcm/connect/bip/bip/urzadmarszalkowski/programy/strategiawojewodzt walodzkiego/strategia_rozwoju_wojewodztwa_lodzkiego_na_lata_2007-2020_2.pdf

Łódzkie region Assembly, The Strategy of Social Policy for Łódzkie region for years 2007-2020, Łódź 2007, dostępna na http://www.rcpslodz.pl/Strategia/19/0/

Malinowska E., Dzwonkowska-Godula K., Świadomość społecznych nierówności płci (Awarness of gender inequalities), [in:] P. Starosta (ed.), Zróżnicowanie zasobów kapitału ludzkiego i społecznego w regionie łódzkim, Wydawnictwo Uniwersytetu Łódzkiego, Łódź 2012

Panek T., Wielowymiarowy pomiar ubóstwa $w$ Polsce w ujęciu regionalnym (Multidimensional measurement of poverty in Poland - regional aspects), "Wiadomości Statystyczne" 2010, nr 2, 18 37

Piwowarski R., Uwarunkowania szkolnictwa zawodowego w województwie łódzkim (Determinants of vocational education development in Lodzkie region), Wyd. Księży Młyn, Łódź, 2009

Przybylski B. K., Zdrowie jako komponent kapitalu ludzkiego (Health as a human capital' component), [in:] P. Starosta (ed.), Zróżnicowanie zasobów kapitału ludzkiego i społecznego w regionie łódzkim, Wydawnictwo Uniwersytetu Łódzkiego, Łódź 2012

Regionalne Centrum Polityki Społęcznej w Łodzi, Bilans potrzeb pomocy społecznej województwa tódzkiego na rok 2011 (Demand for social assistance in Łódzkie region in 2011), Łódź, 2011, http://www.rcpslodz.pl/Bilans_potrzeb/96/1/

Rekomendacje dla ekonomii społecznej w regionie tódzkim (cz. 1). Wnioski z panelu ekspertów (Recommandations for the social economy. Part 1. Results from experts discussion), report from the „Społecznie znaczy ekonomicznie - kontynuacja” Project, Łódź, 2012

Rogut A., Niedopasowanie rynku pracy w województwie tódzkim w zakresie zawodów (Vocational inadjustments on the labour market in Lodzkie region), [in:] E. Kwiatkowski (ed.), Popytowe i podażowe aspekty kapitału ludzkiego w regionie tódzkim(Supply and demand and human capital in Lodzkie region), Wyd. Uniwersytetu Łódzkiego, Łódź 2012

Rogut A., Piasecki B., Regionalna strategia innowacji dla województwa łódzkiego, Łódź 2008, www.pi.gov.pl/PARPFiles/file/lodzkie_RSI.pdf

Rokicka E., Przybylski B. K., Wykształcenie i dodatkowe umiejętności jako komponenty kapitału ludzkiego (Education and additional skills as human capital' components), [in:] P. Starosta (ed.), Zróżnicowanie zasobów kapitału ludzkiego i społecznego w regionie łódzkim, Wydawnictwo Uniwersytetu Łódzkiego, Łódź 2012

Rządowa Rada Ludnościowa (Government Population Council), Sytuacja demograficzna Polski. Raport 2010-2011 (Demographic situation of Poland, 2010-2011), Warszawa 2011, pp. 220-221 
Statistical Office in Katowice. Produkt Krajowy Brutto. Rachunki regionalne w 2009 r. (Gross National Product. Regional accounts, 2009), Katowice 2011, http://www.stat.gov.pl/gus/5840_3594_PLK_HTML.htm

Statistical Office in Łódź, Rynek pracy w województwie tódzkim w latach 2005-2010 (Labour market in Lodzkie region, 2005-2010), Łódź 2011, http://www.stat.gov.p1/lodz/51_PLK_HTML.htm

Strategia rozwoju miasta Lódź 2020+, Lódź, 2012 (Development Stretegy of city of Lodz), www.rzecznik.dlalodzi.info/pliki/.../strategia_rozwoju_miasta_lodz.pdf

Szukalski P., Ludność województwa łódzkiego w perspektywie roku 2035 na tle Polski w świetle prognoz GUS (Population of Lodzkie region up to year 2035 in light of the CSO demographic projection), [w:] P. Szukalski Społeczno-demograficzne wyzwania stojące przed Łodzia i województwem tódzkim (Socio-demographic challenges in Łódź and in Lodzkie region), „Acta Universitatis Lodzensis. Folia Sociologica", nr 35, Wyd. UŁ, Łódź 2010, 7-33

Szukalski P., Sytuacja demograficzna Łodzi (Demographic situation of Lodz), Wyd. Biblioteka, Łódź 2012

Urbaniak B., Wiktorowicz J. (eds.), 2011, Raport z analizy programów skierowanych do osób 50+ zrealizowanych $w$ Polsce $w$ latach 2004-2009 (Report on programmes aimed at people aged 50+ on labour market implemented in Poland in 2004-2009), Wyd. Biblioteka, Łódź

Urząd Marszałkowski w Łodzi, Plan przeciwdziałania depopulacji w województwie tódzkim na lata 20132014 (Plan how to counteract depopulation in Łódzkie region, 2013-2014), Łódź 2012

Warunki życia rodzin wielodzietnych i niepetnych - klientów instytucji pomocy społecznej w województwie tódzkim (Life conditions of families with many children and lone parent families - clients of social assistance in the Lodzkie region) available at http://www.rcpslodz.pl/Opracowania_i_badania/69/1/

Warzywoda-Kruszyńska W., Jankowski B. (2010) Mieszkańcy enklaw biedy 10 lat później (Inhabitants of Lodz’ poverty pockets - 10 years later), Łódź: IS UŁ, Wyd. Biblioteka

Wojtyniak B., P. Goryński (ed.), Sytuacja zdrowotna ludności Polski (Health situation of the Polish population), NIZP -PZH, Warsaw 2008 


\begin{abstract}
ANNEX
Annex 1 Workshop discussion - Lódzkie region

During the OECD visit in March 2012, a regional workshop was organised with four focus groups in Łódź, investigating the impact of demographic change on the future regional and local development scenarios. Following the field study mentioned in section 7.1, "Zaraz wracam" (I'm just going to come back), and DOM (Home), a workshop involving approximately 40 participants was held. The guests included the OECD visitors, Łódź city and region residents, entrepreneurs, representatives of nongovernment organisations (NGOs), and local and regional government institutions. The first part of the meeting covered the presentation of the LEED project, an outline of the activities being undertaken by the regional government to improve human capital, implemented with the assistance of the EU Human Capital Operational Programme, as well as the presentation of the key demographic and social issues in the Łódzkie region and the City of Łódź. The last presentation consisted of an introduction to the work of four focus groups, which focused on options for resolving issues arising at the regional and local levels.
\end{abstract}

The four focus groups concerned respectively:

- Labour markets and older workers: organizational approaches by businesses and trade unions;

- New trends in business and entrepreneurship;

- Sustainable local development;

- Social changes: social inclusion, family-oriented policy and intergenerational exchange.

The focus groups were comprised of between 4 and 11 participants, whose discussions concerning the issues related to the subject-matter of the specific focus was supported by a facilitator using a list of detailed questions elaborated by the OECD and translated by the Ministry for Regional Development.

FOCUS GROUP 1: Labour markets and older workers: organisational approaches by businesses and trade unions

- Participants of this focus group mentioned numerous difficulties faced by older workers in the Polish labour market, both through recruitment, promotion, training or redundancies, and also from the specific organisational culture of Polish enterprises and the expectations of employers towards workers. The disadvantaged situation of older persons within the labour market is due to perceptions that they have lower effectiveness and efficiency, although during the workshop, the participants also mentioned positive effects within enterprises resulting from employing older workers, such as: a better atmosphere at the workplace; fewer absences due to medical reasons; and lower tendency to change jobs.

- Generally, participants lacked confidence that current trends could be changed within this context in the near future, due to the high unemployment rate (including among younger people) in Poland. From a long-term perspective, however, this situation will indeed change, partly as a consequence 
of implementation of the government's currently proposed increase in the retirement age to 67 years.

- The focus group participants highlighted the potential of older workers, and the roles of culture and education as being factors which could significantly increase their ability to remain professionally active and attractive to employers for longer. They also emphasised the need for a two-pronged approach in order to access this potential - the need to strengthen the workers' willingness to invest in themselves, at the very least, to be ready to invest their time; and measures delivered by public institutions. At the same time the "culture and education" sectors could be treated as potentially important employers for older workers.

- The next most important issue flagged was the economic structure and typical size of enterprises in the Łódzkie region. Small enterprises and their owners are focused primarily on survival, thus they omit age management or diversity management.

FOCUS GROUP 2: New business developments and entrepreneurship: the silver economy plus the white economy and the green economy

- The second focus group discussed new trends in business and entrepreneurship. The silver economy was the primary subject of discussion, with the participants mainly talking about new services for citizens aged 55+, and the benefits to the companies offering such services.

- The fact that older people are often unwilling to undertake new activities and are afraid of change, reduces the chances of success for the silver economy as a service, as it is seen as being completely new. Financial expenditure is also limited, as improvement of one's financial status is primarily related to longer-term professional activity, which does not currently occur due to the discrimination felt by 50+ citizens at their workplaces. Participants therefore stressed the need for undertaking initiatives designed to increase the perception of mentoring and guidance as valued services, as this would allow older workers to use their existing skills and work experience, and in this way increase their value to the company. The issue of assisting older people to take part in lifelong learning as the best tool by which to prevent discrimination against them within the labour market was also raised.

- Another subject mentioned concerned the need to implement new services addressed at citizens aged 45+, particularly those services that support and promote activity and which facilitate maintenance of physical fitness in an attractive manner. It was also highlighted that any such new services must additionally be as well adapted as possible to the needs and abilities of older people.

FOCUS GROUP 3: Sustainable local development models: the urban form and social and financial implications of an elderly society

- The third group focused their discussion on the issue of sustainable local development. The fact that all the participants were representatives of either local government institutions or NGOs meant that consideration of services for older citizens were very strongly associated with the operations of the institutions and organisations represented by the participants. They chiefly emphasised that local governments undertake only those measures which are regarded as being simple to implement, and which were further limited by financial constraints. In discussing social services, the workshop participants claimed that in order to best provide access to these, two preliminary conditions must be met: 1) knowledge and information regarding their access; and 2) affordability. In both of these cases, the measures implemented by public institutions were not assessed too highly. Some discrepancies between the strategy provisions and the actual measures implemented by the institutions were observed, which led to some of the intended measures not being accomplished in the way that was originally planned. 
- The workshop participants expressed a strong conviction that services for older people represent an unattractive field of activities for the private sector, thus, in the near future, the public sector will retain the function of the predominant provider of such services, or at least, an entity co-financing them.

- The issue of influencing quality of life of the older population in the region was the final theme highlighted in the discussion. In this context, the discussion focused around three issues: 1) a better public space (easier access and more friendliness towards older citizens); 2) use of free time (managing this in an attractive way so as to raise the interest of older citizens, as well as ensuring it is affordable, and especially focusing on what to offer to inhabitants of small towns and villages); 3) intergenerational links (how to increase contact among representatives of different generations, how to reduce prejudice and improve stereotypes). In this case, the discussion was mainly based on formulating desiderata without identifying specific methods of achieving the above goals.

FOCUS GROUP 4: Social transformations: dynamics of social inclusion, family development and intergenerational solutions

- In the case of focus group four, the participants initially focused on trying to determine which groups face exclusion. The answers provided indicated: 1) People at retirement age; 2) Disabled people; 3) People from poverty-stricken areas; and 4) Women. The participants indicated quite typical examples supporting classification of these groups into the community of excluded/disadvantaged people.

- When asked about the possibility of changing this situation, the participants suggested:

o Greater involvement of the family as a basic supporting institution.

o Systemic changes focused on getting rid of discrimination and improving the situation of these groups.

o A greater role to be played by the Family Assistant - this is a new institution, introduced into the Polish legislation in 2011, with the Assistant being intended to help parents fulfil their social roles, in order to facilitate achievement of basic stability within family life, and to help prevent situations in which children are taken away from their families and placed in institutions and foster families.

o Poor information flow among various institutions, which weakens their operational capacity; and a lack of synergy of actions taken by the individual assistance institutions.

o Establishing a platform of co-operation to help excluded people.

o Increasing sensitivity of employers to those facing exclusion by making them aware of the social responsibility of entrepreneurs.

- The participants also provided examples of measures which, in their opinion, were examples of successful measures. These included: Intergenerational Homes of Social Assistance (facilities which provide social assistance homes for older people and homes for children under the one roof); the "Flying Grannies" system (a group of women aged 55+, who help to make the stay of children in educational and care institutions nicer, through delivery of literature and theatreoriented activities - see Box 5); and Multigenerational Theatre.

- The participants also mentioned another initiative, Partnership for Łódź, proposed by John Godson, a Member of Parliament, which focuses on co-ordinated activities designed to prevent the development of poverty in Łódź, particularly of 'poverty pockets', by developing a system of social assistance infrastructure comprising clubs and co-operatives.

- Apart from the examples of positive activities, the participants also mentioned areas of evident difficulties and shortages. For instance, there is no commissioner for disabled people, thus, there is 
no information specifically addressed to them ${ }^{48}$. There is also no support for women who want to have children, but also wish to return to work after maternity leave, because there is no child-care assistance or nurseries, hence, they are unable to return to work after their children are born.

- It was also emphasised that flexible forms of employment provide an opportunity for young mothers, or women who want to start a family and raise their children. The need to influence the awareness of employers, which also reflects the lack of sensitivity to the issue of job stability, was also mentioned.

- The theme of bureaucracy, which complicates delivery of assistance, and the need for implementation of systemic solutions that facilitate the social interaction of parents, were also raised during the discussion.

\section{Concluding Remarks}

The meeting was concluded with a presentation of the key findings of the focus groups and comments formulated by the OECD experts.

- The experts highlighted the complexity of the Lódź Region's situation of shrinking population, ageing and unemployment due to redundancies.

- The experts also found evidence that there is a tendency to think in the short-term, whereas in policy making, there is a need to think of the medium and longer terms, not only at a national level but also at a regional one. While there may not be a problem now, in the future there could be substantial problems.

- The experts also noted the importance of being proactive. Policy making needs to look ahead. Particularly in a region that is currently experiencing economic problems, it is necessary to make sure the conditions for progress and growth exist. If there are shortages of people in the future, this will make growth very difficult.

A very important theme was the need for flexibility. Working longer does not necessarily mean working at the same position or in the same job. Career opportunities are also very important, and the need to provide opportunities to combine the different careers options that individuals have available to them.

\footnotetext{
${ }^{48}$ There is in fact a commissioner (Ewa Ściborska), but she acts as a commissioner for disabled people in Łódź only (working at the town hall). There is no plenipotentiary for disabled people at a regional level.
} 


\section{Annex 2 Note on Contributors}

Professor Piotr Szukalski obtained his PhD in economics at the University of Lódź, where he works as the Chair of Applied Sociology and Social Work. He has published over 200 articles and chapters related to social gerontology, demography, intergenerational relations and family issues. His research interests are in family care-giving, older adults' activities, economic activity of the elderly, ageism, and intergenerational relations. He has been the recipient of research grants from the Polish Committee of Scientific Research in the areas of population ageing and social policy (Family status of the oldest old and their economic and health status, 2002-2004; The oldest old - demographic and epidemiological studies, 2006-2008), the Institute of Public Affairs (Withdrawal or participation? Social and professional activity during retirement, 2006-2007), National Research Centre (Marriage: beginnings and ends, 20112013), Ministry of Labour and Social Policy (Equalising chances of people aged 45+ in the Polish labour market, 2010-2013). Szukalski was involved with international research projects - including the IPROSEC (Improving Policy Responses and Outcomes to Socio-Economic Challenges: changes to family structures, policy, and practice, 5FP, co-ordinator: Linda Hantrais) - member of the national research team - and the PROFIT (Policy Responses Overcoming Factors in Intergenerational Transmission of inequalities, 6FP, coordinator: Wielisława Warzywoda-Kruszyńska) - member of the Co-ordinating Team. In recent years, Dr Szukalski was author and co-editor of 4 books, including Przeplywy międzypokoleniowe $i$ ich kontekst demograficzny (Intergenerational Transfers and the Demographic Change), Nasze starzejące się społeczeństwo. Nadzieje i zagrożenia (Our Aging Society. Opportunities and Threatens), Rodzina $w$ zmieniajacym się społeczeństwie polskim (Family in the Changing Polish Society); Starość i starzenie się jako doświadczenie jednostek i zbiorowości ludzkich (Old age and ageing as an individual and population experience).

Dr Cristina Martinez-Fernandez is a Senior Policy Analyst on Employment and Skills, Green Growth and South-East Asia at the Organisation for Economic Co-operation and Development (OECD), Local Economic and Employment Development (LEED) programme. She works on issues related to the challenges of skills and training systems for SMEs, entrepreneurial and innovation activities; industrial policy, climate change and the transformation of labour markets into the low-carbon economy; the challenges of demographic change and an ageing society for skills and employment development. Cristina also manages the OECD/LEED Initiative on Employment and Skills Strategies in Southeast Asia (ESSSA). Before joining the OECD, she was an Associate Professor at the Urban Research Centre, University of Western Sydney in Australia, where she led the Urban and Regional Dynamics Programme, which analyses industry change, urban performance and socio-economic development within the frameworks of innovation, globalisation and the knowledge economy.

Dr Tamara Weyman works as a contracted expert for the OECD, working on various projects involving employment and skills, SMEs development, South-East Asia, territorial development policy, and demographic change and sustainability. Recently, Tamara has been involved in publications such as 'Martinez-Fernandez, C.; I.Miles; T.Weyman (2012) The Knowledge Economy at Work: Skills and Innovation in Knowledge Intensive Services Activities, Edward Elgar; Martinez-Fernandez, C.; P.Chorazy; T.Weyman; and M.Gawron. (2011), The Territorial Dimension of the European Social Fund: A Local Approach for Local Jobs, OECD; OECD (2012) Skills development and Training in SMEs, OECD publishing; Martinez-Fernandez, C.; N.Kubo; A.Noya; and T.Weyman (2012), Demographic Change and Local Development: Shrinkage, Regeneration and Social Dynamics, OECD; and a chapter in a forthcoming book, Schatz, L.; D.Leadbeater; C.Martinez-Fernandez; and T.Weyman (2013), 'From "up north" to "down under”: Dynamics of shrinkage in mining communities in Canada and Australia' in Stories of Tough Times: International perspectives and policy implication in shrinking cities, Routledge. Tamara worked as a Research Associate at the Urban Research Centre, University of Western Sydney (UWS) and completed her PhD on Spatial Information Sharing for Better Regional Decision Making in 
56 | ANNEX

2007 at UWS. Since 2009, Tamara has been involved in the COST Action TU 0803 "Cities Regrowing Smaller". 


\title{
ŁÓDZKIE REGION:
}

\author{
DEMOGRAPHIC CHALLENGES \\ WITHIN AN IDEAL LOCATION
}

